\title{
Os limites à quebra do sigilo da(s) fonte(s) jornalística(s), à luz da jurisprudência do Tribunal Europeu dos Direitos Humanos*
}

\section{The Limits to the Disclosure of Journalistic Source(S), in the Light of the Jurisprudence of the European Court of Human Rights}

\section{Hidemberg Alves da Frota**}

SumÁrio: I. Introdução. II. O Tribunal Europeu dos Direitos Humanos (TEDH). III. O sigilo da(s) fonte(s) jornalística(s) como desdobramento da liberdade de expressão. IV. Os critérios empregados pelo TEDH para avaliar se houve indevida relativização do sigilo da(s) fonte(s) jornalística(s). IV. Correição Parcial no. 2008.72.00.005353-8/SC (7 Turma do TRF/ $\left.4^{a}\right)$. V. Conclusão. VI. Referências.

* Artículo recibido el 12 de marzo de 2011 y aprobado para publicación el 28 de septiembre de 2011.

À Fernanda Leite Bião, a luz da minha alma. Ao reencontrá-la a cada dia, reaviva-se a presença de Deus em minha vida, espelhada em seu sorriso e realçada por seu amor, dedicação e integridade. Obrigado por existir em minha vida e por me permitir compartilhar da sua caminhada existencial, ensinando-me dia a dia, por meio de sua conduta, novas lições de humanismo, simplicidade d'alma, renovação íntima e apreço pelos diferentes olhares e modos de ser que compõem e enriquecem o mosaico cultural da humanidade.

** Advogado. Pesquisador em direito público e em direitos da personalidade. 
RESUMEN: Este artículo extrae de la casuística del Tribunal Europeo de Derechos Humanos los elementos empíricos y teóricos para una visión amplia de la doctrina del Tribunal sobre la divulgación de las fuentes periodísticas y de los contextos fácticos y jurídicos que el mismo Tribunal ha establecido y perfeccionado sobre su línea de pensamiento acerca de esta controversia para contribuir al estudio científico de la materia y la resolución de casos específicos dentro de la práctica jurídica.

Palabras clave: libertad de prensa, divulgación de las fuentes periodísticas, casuística, jurisprudencia del Tribunal Europeo de Derechos Humanos.

ABSTRACT: This article extracts from the casuistry of the European Court of Human Rights empirical and theoretical elements for a broad view of the doctrine of the Court on the disclosure of journalistic sources and of the factual and legal contexts in the light of which the Strasbourg Court has established and perfected its line of thinking about this controversy to contribute to the scientific study of matter and the resolution of specific cases within the legal practice

Keywords: freedom of the press, disclosure of journalistic sources, casuistry, jurisprudence of the European Court of Human Rights.

RÉSUMÉ: Cet article obtient de la casuistique de la Cour européenne des droits de l'homme les éléments empiriques et théoriques pour une vue plus grande de la doctrine de la Cour sur la divulgation des sources journalistiques et les contextes factuels et juridiques de la Cour elle-même a établi et amélioré dans sa line de pensée à propos de cette controverse pour contribuer à l'étude scientifique de la matière et la résolution des affaires spécifiques dans la pratique juridique.

Mots-clés: liberté de la presse, la divulgation des sources journalistiques, la casuistique, la jurisprudence de la Cour Européenne des Droits de l'Homme. 


\section{INTRODUÇÃO}

Controvérsia pouco explorada pela dogmática brasileira, a discussão em torno da possibilidade de quebra judicial do sigilo da(s) fonte(s) jornalística(s), como medida voltada à instrução processual penal e ao esclarecimento da autoria de ilícitos (sobretudo, penais), recebe fecundos contributos da jurisprudência remansosa do Tribunal Europeu dos Direitos Humanos.

A análise da jurisprudência iterativa da Corte de Estrasburgo concernente ao sigilo jornalístico permite ao cultor do Direito conhecer situações em que membros do Ministério Público e do Poder Judiciário se veem instados a ponderar a respeito da relevância de se identificar(em) a(s) pessoa(s) que serviu(ram) de fonte(s) jornalística(s), a fim de o Estado viabilizar, desse modo, a persecução penal e a prevenção de delitos e danos indenizáveis, inclusive violações a sigilos e segredos da vida privada, em cotejo com a importância de se preservar o sigilo profissional dos jornalistas e de se evitar que tais medidas instrutórias (mormente, de cunho penal) inibam a liberdade de informação jornalística, em prejuízo do exercício da atividade jornalística e de seu múnus societário, da fiscalização da sociedade e dos meios de comunicação social sobre a conduta do Poder Público, do acesso da coletividade a informações de interesse público (colhidas das esferas pública e privada) e da vitalidade do regime democrático.

A cada julgado, enriquece-se a referida construção pretoriana, mediante a alvorada de novéis casos concretos de estudo, oportunidades para os profissionais do Direito aferirem em que contextos se aplica tal construto jurisprudencial, as nuanças das situações examinadas pelo Tribunal Europeu dos Direitos Humanos, os desdobramentos in concreto da quebra do sigilo jornalístico, os aspectos nevrálgicos e os argumentos - contrários e favoráveis - ao mencionado provimento jurisdicional, de acordo com as particularidades das circunstâncias analisadas, além de constituírem ensejo para o estudo das achegas teoréticas que florescem, no seio da Corte de Estrasburgo, à medida que se consolida o pensamento do TEDH e, ao mesmo tempo, desenvolvem-se as balizas delineadas pela Corte Europeia, à proporção que enfrenta, de forma reiterada, a vexata quaestio objeto deste artigo jurídico e torna seu acervo 
de julgamentos fonte permanente e renovada de sementes de reflexão acerca das eventuais hipóteses de quebra judicial do sigilo da(s) fonte(s) jornalística(s).

Neste trabalho, ab initio, consignam-se noções basilares atinentes ao Tribunal Europeu dos Direitos Humanos e à liberdade de expressão na Convenção Europeia dos Direitos Humanos, o marco normativo em que se baseia o TEDH, ao invocar a proteção da liberdade de informação jornalística e considerar hipóteses de relativização do sigilo jornalístico.

Em seguida, analisam-se os critérios adotados pela jurisprudência do Tribunal Europeu dos Direitos Humanos para perscrutar se uma ordem judicial de quebra do sigilo da(s) fonte(s) jornalística(s) viola a proteção à liberdade de expressão tal como insculpida no art. 10 da Convenção Europeia dos Direitos Humanos.

Trazem-se a lume as considerações em abstrato do TEDH sobre o resguardo à liberdade de imprensa e os requisitos divisados pela Corte de Estrasburgo para a quebra judicial do sigilo jornalístico, a par de se comentarem peculiaridades dos casos concretos com os quais se deparou aquela Corte Europeia, com vistas a contextualizar a aplicação in concreto da doutrina forjada pelo Tribunal Europeu dos Direitos Humanos.

Almeja-se, desse modo, propiciar à comunidade jurídica elementos teóricos e empíricos pertinentes seja ao aprofundamento e à ampliação dessa linha de pesquisa jurídica, seja ao enfrentamento, no cotidiano forense, de circunstâncias análogas, no que forem compatíveis com os contextos fático-jurídicos a figurarem como fundo de pano das decisões promanadas do Tribunal Europeu dos Direitos Humanos.

Ao final, à guisa de complemento à referida jurisprudência reiterada do TEDH, comenta-se, no âmbito do Direito brasileiro, o aresto da Sétima Turma do Tribunal Regional Federal da Quarta Região atinente à Correição Parcial no 2008.72.00.005353-8/SC (Relator, Desembargador Federal Néfi Cordeiro), julgada em 3 de novembro de 2009.

\section{O Tribunal EURopeu dos Direitos Humanos (TEDH)}

Oficialmente nominado Cour Européenne des Droits de l'Homme ou European Court of Human Rights (seus idiomas oficiais são o francês e o inglês), 
o Tribunal Europeu dos Direitos Humanos-TEDH está sediado no Nordeste da França, em Estrasburgo (motivo por que também é conhecido como Corte de Estrasburgo $)^{1}$.

Desde 23 de fevereiro de 1959, atua na qualidade de guardião e intérprete oficial ou autêntico da Convenção Europeia dos Direitos HumanosCEDH (também denominada, oficialmente, de Convenção para a Proteção dos Direitos do Homem e das Liberdades Fundamentais), de 4 de novembro de 1950, nos termos dos arts. 19 e 32, n 1 , do referido tratado. ${ }^{2}$

Ao contrário do Tribunal de Justiça das Comunidades Europeias (também conhecido como Tribunal de Justiça da União Europeia, Tribunal Europeu de Justiça ou Corte de Luxemburgo), do Tribunal de Primeira Instância e do Tribunal da Função Pública, o Tribunal Europeu dos Direitos Humanos não é órgão jurisdicional da União Europeia, e sim, do Conselho da Europa-COE, organismo internacional que, na atualidade (janeiro de 2010), possui, como membros, 47 (quarenta e sete) Estados europeus. $^{3}$

OTEDH se tornou órgão permanente do Conselho da Europa por meio da reforma do art. 19 da CEDH realizada pelo Protocolo n. 11, que entrou em vigência ${ }^{4}$ em $1^{\circ}$ de novembro de 1998 , e, dentre outras alterações, modificou a redação do art. 34 da CEDH, ao estender a qualquer pessoa que se considere vítima de violações, por Estados que assinaram e ratificaram a Convenção (Estados contratantes — Contracting States ou États contractants), de direitos agasalhados na CEDH e em seus Protocolos (inclusive organizações não governamentais e grupos de indivíduos)

1 Frota, Hidemberg Alves da, O princípio tridimensional da proporcionalidade no Direito Administrativo: um estudo à luz da Principiologia do Direito Constitucional e Administrativo, bem como da jurisprudência brasileira e estrangeira, Rio de Janeiro, GZ, 2009, p. 6-7.

2 Conselho Da Europa, Convention for the Protection of Human Rights and Fundamental Freedoms as amended by Protocols N. 11 and N. 14. Disponível em: http://conventions.coe. int/treaty/en/Treaties/Html/005.htm. Acesso em: 5 jan. 2011.

3 Id. The Court in brief. Disponível em: http: / /www.echr.coe.int/NR/rdonlyres/DF074FE496C2-4384-BFF6-404AAF5BC585/0/Brochure_en_bref_EN.pdf. Acesso em: 5 jan. 2011. Nesse sentido: Frota, Hidemberg Alves da, op. cit., loc. cit.

${ }^{4}$ Acolhe-se a ponderação de que a vigência alude ao intervalo de tempo durante o qual dada norma jurídica possui força vinculante, ao passo que o vigor concerne à efetividade dos seus efeitos jurídicos. Cf. Gagliano, Pablo Stolze e Pamplona Filho, Rodolfo, Novo curso de direito civil: parte geral, 10. ed., São Paulo, Saraiva, v. 1, p. 56, 59, 65. 
o direito de provocar, diretamente, a jurisdição do Tribunal Europeu de Direitos Humanos. ${ }^{5}$

\author{
III. O SIGILO DA(S) FONTE(S) JORNALÍSTICA(S) \\ COMO DESDOBRAMENTO DA LIBERDADE DE EXPRESSÃO
}

\begin{abstract}
A Convenção para a Proteção dos Direitos do Homem e das Liberdades Fundamentais agasalha a liberdade de expressão em seu art. 10, in verbis:
\end{abstract}

Artigo $10^{\circ}$

Liberdade de expressão

1. Qualquer pessoa tem direito à liberdade de expressão. Esse direito compreende a liberdade de opinião e a liberdade de receber ou de transmitir informações ou ideias sem que possa haver ingerência de quaisquer autoridades públicas e sem considerações de fronteiras. O presente artigo não impede que os Estados submetam as empresas de radiodifusão, de cinematografia ou de televisão a um regime de autorização prévia.

2. O exercício dessas liberdades, porquanto implica deveres e responsabilidades, pode ser submetido a certas formalidades, condições, restrições ou sanções, previstas pela lei, que constituam providências necessárias, numa sociedade democrática, para a segurança nacional, a integridade territorial ou a segurança pública, a defesa da ordem e a prevenção do crime, a proteção da saúde ou da moral, a proteção da honra ou dos direitos de outrem, para impedir a divulgação de informações confidenciais, ou para garantir a autoridade e a imparcialidade do poder judiciário. ${ }^{6}$ (grifo nosso)

5 Id. Protocol N. 11 to the Convention for the Protection of Human Rights and Fundamental Freedoms, E.T.S. 155, entered into force 1 November 1998. Disponível em: http:// www1.umn.edu/humanrts/euro/z30prot11.html. Acesso em: 5 jan. 2011.

6 Conselho Da Europa, Convenção para a Protecção dos Direitos do Homem e das Liberdades Fundamentais, com as modificações introduzidas pelos Protocolos ns. 11 e 14, acompanhada do Protocolo adicional e dos Protocolos ns. 4, 6, 7 e 13. Disponível em: http:// www.echr.coe.int/NR/rdonlyres/7510566B-AE54-44B9-A163-912EF12B8BA4/0/POR_CONV. pdf. Acesso em: 5 jan. 2011, redação da tradução oficial, em português europeu, ajustada por nós ao português brasileiro. 
Da leitura do supracitado art. 10-1 da Convenção Europeia dos Direitos Humanos, percebe-se que a liberdade de expressão, tal como insculpida na CEDH, abarca tanto a liberdade de opinião quanto a liberdade de informação, o que explica a razão da jurisprudência consolidada do Tribunal Europeu dos Direitos Humanos ter avistado em tal artigo preceito a proteger a liberdade de imprensa, uma vez que a liberdade de imprensa abrange seja a liberdade de opinião jornalística, seja a liberdade informação jornalística propriamente dita.

No referido dispositivo da Convenção, o Tribunal Europeu dos Direitos Humanos divisou o respaldo normativo para a proteção das fontes jornalísticas, vislumbrada pelo TEDH como condição sine qua non para a liberdade de imprensa: na óptica da Corte de Estrasburgo, sem essa salvaguarda, as fontes podem ser obstadas de assistir a imprensa em informar à coletividade acerca de matérias de interesse público, o que prejudicaria a função fiscalizadora dos meios de comunicação social e a capacidade destes de proporcionarem ao corpo social informações precisas e confiáveis.

Em virtude da relevância que possui a proteção das fontes jornalísticas para a liberdade de imprensa em uma sociedade democrática e do potencial efeito inibitório que uma ordem de quebra de sigilo jornalístico teria sobre o exercício dessa liberdade, a jurisprudência remansosa do TEDH tem considerado incompatíveis com o direito à liberdade de expressão previsto no art. $10 \mathrm{da} \mathrm{CEDH}$ as determinações estatais de quebra de sigilo jornalístico, salvo se justificáveis diante de uma preponderante exigência do interesse público ("unless it is justified by an overriding requeriment in the public interest"; "si elle se justifie par un impératif prépondérant d'intérêt public”), harmônica com as balizas do mencionado parágrafo segundo do mesmo artigo.

Cuida-se do posicionamento da Corte de Estrasburgo sobre o sigilo $\mathrm{da}(\mathrm{s})$ fonte(s) jornalística(s) assente desde o acórdão paradigma formulado pela sua Grande Câmara em Goodwin v. the United Kingdom ${ }^{7}$ (§ 39), de 27 de março de 1996, reiterado quer pela Terceira Seção, em Voskuil

Conselho Da Europa. European Court of Human Rights (Grand Chamber). Goodwin v. the United Kingdom (Application n. 17488/90). Strasbourg, 27 March 1996. Disponível em: http: / / www.echr.coe.int/ECHR. Acesso em: 6 jan. 2011. 
v. The Netherlands ${ }^{8}(\S 65)$, de 22 de novembro de 2007, e em Sanoma Uitgevers B.V.v. The Netherlands ${ }^{9}(\S 54, d)$, de 31 de março de 2009, quer pela Quarta Seção, em Roemen and Schmit v. Luxembourg ${ }^{10}(\S 46)$, de 25 de fevereiro de 2003, e em Financial Times Ltd and Others v. The United Kingdom $^{11}$ (§ 59), de 15 de dezembro de 2009, assim como pela Primeira Seção, em Nordisk Film \&TV A/S v. Denmark, ${ }^{12}$ de 8 de dezembro de 2005.

\section{OS CRITÉRIOS EMPREGADOS PELO TEDH PARA AVALIAR SE HOUVE INDEVIDA RELATIVIZAÇÃO DO SIGILO DA(S) FONTE(S) JORNALÍSTICA(S)}

A fim de verificar se, no caso concreto, a relativização da garantia do sigilo jornalístico poderia se apoiar nas hipóteses excepcionais delineadas pelo indicado art. 10-2 da CEDH, a Grande Câmara do Tribunal Europeu dos Direitos Humanos, em Goodwin v. the United Kingdom ${ }^{13}$ ( $\S \S$ 28 a 46), indagou se a interferência estatal, de acordo com o contexto in concreto, (1) foi prescrita por lei (prescribed by law; prévues par la loi), isto é, se estava prevista no correspondente Direito interno (se possuía respaldo na ordem jurídica do respectivo Estado contratante), (2) visou à finalidade legítima (legitimate aim; but légitime) e (3) era necessária em uma sociedade democrática (necessary in a democratic society; nécessaire dans une

8 Conselho Da Europa, European Court of Human Rights (Third Section). Voskuil v. The Netherlands (Application n. 64752/01). Strasbourg, 22 November 2007. Disponível em: http://www.echr.coe.int/ECHR. Acesso em: 6 jan. 2011.

9 Conselho Da Europa, European Court of Human Rights (Third Section). Sanoma Uitgevers B.V.v. The Netherlands (Application n. 38224/03). Strasbourg, 31 March 2009. Disponível em: http: / / www.echr.coe.int/ECHR. Acesso em: 6 jan. 2011.

10 Conselho Da Europa, European Court of Human Rights (Fourth Section). Roemen and Schmit v. Luxembourg (Application n. 51772/99). Strasbourg, 25 February 2003. Disponível em: http://www.echr.coe.int/ECHR. Acesso em: 6 jan. 2011.

1 Conselho Da Europa, European Court of Human Rights (Fourth Section). Financial Times Ltd and Others v. The United Kingdom (Application n. 821/03). Strasbourg, 15 December 2009. Disponível em: http://www.echr.coe.int/ECHR. Acesso em: 6 jan. 2011.

12 Conselho Da Europa. European Court of Human Rights (First Section). Nordisk Film \& TV A/S v. Denmark (Application n. 40485/02). Strasbourg, 8 December 2005. Disponível em: http: / / www.echr.coe.int/ECHR. Acesso em: 6 jan. 2011.

13 CONSElHO DA EUROPA. European Court of Human Rights (Grand Chamber). Goodwin v. the United Kingdom (Application n. 17488/90). Strasbourg, 27 March 1996. Disponível em: http: / / www.echr.coe.int/ECHR. Acesso em: 6 jan. 2011. 
société démocratique), ou seja, se correspondia a uma premente necessidade social.

Essa formulação tridimensional do princípio da proporcionalidade no tocante ao exame de alegação de quebra de sigilo da(s) fonte(s) jornalística(s) restou observada, na Corte de Estrasburgo, pela Primeira Seção (Nordisk Film \& TV A/S v. Denmark), ${ }^{14}$ Segunda Seção (Ernst et Autres c. Belgique ${ }^{15}, \S \S 96$ a 105; Tillack c. Belgique, $\S \S 58$ a 68 ${ }^{16}$ ) e Quarta Seção (Roemen and Schmit v. Luxembourg, ${ }^{17} \S \S 47$ a 60; Financial Times Ltd and Others v. The United Kingdom, ${ }^{18} \S \S 56$ a 73).

Já a Terceira Seção do TEDH, em Voskuil v. The Netherlands ${ }^{19}$ ( $\S 49$ a 74), assim como em Sanoma Uitgevers B.V. v. The Netherlands ${ }^{20}$ ( $\S 49$ a 63), antes de se debruçar sobre os 3 (três) indicados critérios de aferição, adotou, como primeira baliza, o questionamento quanto à presença de interferência em direito encastoado no art. 10 da CEDH. Em outras palavras, em tais precedentes, a Terceira Seção da Corte de Estrasburgo

14 O aresto do caso Nordisk Film \& TV A/S v. Denmark não foi dividido em parágrafos, ao contrário do que ocorre com parcela expressiva dos acórdãos do Tribunal Europeu dos Direitos Humanos.

Conselho Da Europa. European Court of Human Rights (First Section). Nordisk Film \&TV A/S v. Denmark (Application n. 40485/02). Strasbourg, 8 December 2005. Disponível em: http: / / www.echr.coe.int/ECHR. Acesso em: 6 jan. 2011.

15 Conselho Da Europa. Cour européenne des Droits de l'Homme (deuxième section). Ernst et Autres v. Belgique (Requête n. 33400/96). Strasbourg, 15 juillet 2003. Disponível em: http://www.echr.coe.int/ECHR. Acesso em: 6 jan. 2011.

${ }_{16}$ Conselho Da Europa. Cour européenne des Droits de l'Homme (deuxième section). Tillack c. Belgique (Requête n. 20477/05). Strasbourg, 15 juillet 2003. Disponível em: http: / / www.echr.coe.int/ECHR. Acesso em: 6 jan. 2011.

17 CONSELHO DA EUROPA. European Court of Human Rights (Fourth Section). Roemen and Schmit v. Luxembourg (Application n. 51772/99). Strasbourg, 25 February 2003. Disponível em: http: //www.echr.coe.int/ECHR. Acesso em: 6 jan. 2011.

18 Conselho Da Europa. European Court of Human Rights (Fourth Section). Financial Times Ltd and Others v. The United Kingdom (Application n. 821/03). Strasbourg, 15 December 2009. Disponível em: http: / /www.echr.coe.int/ECHR. Acesso em: 6 jan. 2011.

19 Conselho Da Europa. European Court of Human Rights (Third Section). Voskuil v. The Netherlands (Application n. 64752/01). Strasbourg, 22 November 2007. Disponível em: http: / / www.echr.coe.int/ECHR. Acesso em: 6 jan. 2011.

20 Conselho Da Europa. European Court of Human Rights (Third Section). Sanoma Uitgevers B.V.v. The Netherlands (Application n. 38224/03). Strasbourg, 31 March 2009. Disponível em: http: / / www.echr.coe.int/ECHR. Acesso em: 6 jan. 2011. 
averiguou se a atuação do Poder Público, à luz da circunstância concreta analisada, (1) configurou interferência em direito assegurado pelo art. $10 \mathrm{da}$ CEDH, bem assim se a interferência, uma vez comprovada, (2) foi prescrita por lei, (3) voltou-se à finalidade legítima e se mostrou (4) necessária em uma sociedade democrática.

Após aferido, pelo Tribunal Europeu dos Direitos Humanos, que determinado requisito dessa formulação trina ou quadripartida do princípio da proporcionalidade não foi plenamente atendido pelo Estado contratante, pode ocorrer da mencionada Corte Europeia reputar prejudicado o exame do(s) critério(s) subsequente(s), a exemplo do julgamento, pela Grande Câmara do TEDH, concernente ao caso Sanoma Uitgevers B.V. v. The Netherlands ${ }^{21}$ (§§ 94, 100 e 101), quando, em 14 de setembro de 2010, o órgão maior da Corte de Estrasburgo, atuando como segunda instância (na qualidade de instância revisora da Terceira Seção daquela Corte), deixou de verificar se, na circunstância concreta analisada, a quebra estatal do sigilo jornalístico visava à finalidade legítima e fora necessária em uma sociedade democrática, bastando-lhe (para considerar contrário ao art. 10 da CEDH o ato de descerramento de tal sigilo e, em consequência, condenar o Estado contratante demandado ao pagamento de valor indenizatório) chegar à inferência de que a medida impugnada não se encontrava devidamente prescrita por lei.

\section{O critério da prescrição por lei}

Ao examinar se uma interveniência estatal na garantia do sigilo jornalístico resta prescrita por lei, o Tribunal Europeu dos Direitos Humanos perquire se houve a chancela do Direito Legislado (Grande Câmara, Goodwin v. the United Kingdom, ${ }^{22} \S 29$; Primeira Seção, Nordisk Film \&

21 Conselho Da Europa. European Court of Human Rights (Grand Chamber). Sanoma Uitgevers B.V.v. The Netherlands (Application n. 38224/03). Strasbourg, 14 September 2010. Disponível em: http: / / www.echr.coe.int/ECHR. Acesso em: 6 jan. 2011.

22 Conselho Da Europa. European Court of Human Rights (Grand Chamber). Goodwin v. the United Kingdom (Application n. 17488/90). Strasbourg, 27 March 1996. Disponível em: http: / / www.echr.coe.int/ECHR. Acesso em: 6 jan. 2011. 
TV A/S v. Denmark; ${ }^{23}$ Segunda Seção, Tillack c. Belgique, §§ 32 e 58; $;^{24}$ Terceira Seção, Sanoma Uitgevers B.V.v. The Netherlands, ${ }^{25} \S 51$, e Voskuil v. The Netherlands, ${ }^{26} \S 50$; Quarta Seção, Roemen and Schmit v. Luxembourg, ${ }^{27}$ $\S 49$, e Financial Times Ltd and Others v. The United Kingdom, $\left.{ }^{28} \S 57\right)$, encontrando tal respaldo, por vezes, na legislação processual penal apontada pelo Estado contratante demandado (Segunda Seção, Tillack c. Belgique, $\S \S 32$ e 58; ${ }^{29}$ Quarta Seção, Roemen and Schmit v. Luxembourg, ${ }^{30} \S 49$; Terceira Seção, Sanoma Uitgevers B.V. v. The Netherlands, ${ }^{31} \S 51$; Terceira Seção, Voskuil v. The Netherlands, $\left.{ }^{32} \S 50\right)$.

23 Conselho Da Europa. European Court of Human Rights (First Section). Nordisk Film \& TVA/S v. Denmark (Application n. 40485/02). Strasbourg, 8 December 2005. Disponível em: http: / / www.echr.coe.int/ECHR. Acesso em: 6 jan. 2011.

${ }^{24}$ Conselho Da Europa. Cour européenne des Droits de l'Homme (deuxième section). Tillack c. Belgique (Requête n. 20477/05). Strasbourg, 15 juillet 2003. Disponível em: http: / / www.echr.coe.int/ECHR. Acesso em: 6 jan. 2011.

25 Conselho Da Europa. European Court of Human Rights (Third Section). Sanoma Uitgevers B.V.v. The Netherlands (Application n. 38224/03). Strasbourg, 31 March 2009. Disponível em: http: / / www.echr.coe.int/ECHR. Acesso em: 6 jan. 2011.

26 Conselho Da Europa. European Court of Human Rights (Third Section). Voskuil v. The Netherlands (Application n. 64752/01). Strasbourg, 22 November 2007. Disponível em: http: / / www.echr.coe.int/ECHR. Acesso em: 6 jan. 2011.

27 Conselho Da Europa. European Court of Human Rights (Fourth Section). Roemen and Schmit v. Luxembourg (Application n. 51772/99). Strasbourg, 25 February 2003. Disponível em: http://www.echr.coe.int/ECHR. Acesso em: 6 jan. 2011.

28 Conselho Da Europa. European Court of Human Rights (Fourth Section). Financial Times Ltd and Others v. The United Kingdom (Application n. 821/03). Strasbourg, 15 December 2009. Disponível em: http://www.echr.coe.int/ECHR. Acesso em: 6 jan. 2011.

29 Conselho Da Europa. Cour européenne des Droits de l'Homme (deuxième section). Tillack c. Belgique (Requête n. 20477/05). Strasbourg, 15 juillet 2003. Disponível em: http: / / www.echr.coe.int/ECHR. Acesso em: 6 jan. 2011.

30 Conselho Da Europa. European Court of Human Rights (Fourth Section). Roemen and Schmit v. Luxembourg (Application n. 51772/99). Strasbourg, 25 February 2003. Disponível em: http://www.echr.coe.int/ECHR. Acesso em: 6 jan. 2011.

31 Conselho Da Europa. European Court of Human Rights (Third Section). Sanoma Uitgevers B.V. v. The Netherlands (Application n. 38224/03). Strasbourg, 31 March 2009. Disponível em: http: / / www.echr.coe.int/ECHR. Acesso em: 6 jan. 2011.

32 Conselho Da Europa. European Court of Human Rights (Third Section). Voskuil v. The Netherlands (Application n. 64752/01). Strasbourg, 22 November 2007. Disponível em: http: / / www.echr.coe.int/ECHR. Acesso em: 6 jan. 2011. 
Em Financial Times Ltd and Others v.The United Kingdom ${ }^{33}$ (§57), a Quarta Seção do Tribunal Europeu dos Direitos Humanos considerou, além da previsão em ato legislativo, o supedâneo haurido da jurisprudência consolidada no respectivo Direito interno — nesse contexto, acórdãos paradigmas no âmbito do ordenamento jurídico do Reino Unido da Grã-Bretanha e Irlanda do Norte relativamente ao acesso judicial a informações confidenciais.

In casu, cuidava-se do precedente da Câmara dos Lordes ${ }^{34}$ atinente ao caso Norwich Pharmacal Co. v The Commissioners of Customs and Excise [1974] RPC 101, aresto britânico também levado em conta pela Grande Câmara da Corte de Estrasburgo em Goodwin v. the United Kingdom (§ 33), ${ }^{35}$

33 Conselho Da Europa. European Court of Human Rights (Fourth Section). Financial Times Ltd and Others v. The United Kingdom (Application n. 821/03). Strasbourg, 15 December 2009. Disponível em: http://www.echr.coe.int/ECHR. Acesso em: 6 jan. 2011.

34 A função jurisdicional da Câmara dos Lordes do Parlamento do Reino Unido da Grã-Bretanha e Irlanda do Norte, até então exercida pelo Colegiado Judicial (Committee of Law Lords) daquela Câmara Alta, constituído pela parcela de magistrados (Lords of Appeal in Ordinary) do seu corpo de Lordes, foi extinta com o estabelecimento da Suprema Corte do Reino Unido (Supreme Court of the United Kingdom), efetivado em $1^{\circ}$ de outubro de 2009, nos termos da Parte 3 da Lei de Reforma Constitucional de 2005, que buscou escoimar dos órgãos judiciários o exercício de atos executivos e legislativos, a fim de contemplar a exigência de órgãos judicantes independentes e imparciais, conforme preceitua o art. $6^{\circ}-1$ da Convenção Europeia dos Direitos Humanos. A Suprema Corte do Reino Unido é a instância judiciária máxima da Inglaterra, do País de Gales, da Irlanda do Norte e da Escócia, salvo, no caso desta, as matérias penais, sob a incumbência da Corte Superior do Judiciário da Escócia (High Court of Justiciary). Cf. Wikipedia. Constitutional Reform Act 2005. Disponível em: http://en.wikipedia. org/wiki/Constitutional_Reform_Act_2005. Acesso em: 26 jan. 2011; Wikipedia. High Court of Justiciary. Disponível em: http://en.wikipedia.org/wiki/High_Court_of_Justiciary. Acesso em: 26 jan. 2011; Wikipedia. Lords of Appeal in Ordinary. Disponível em: http://en.wikipedia. org/wiki/Lords_of_Appeal_in_Ordinary. Acesso em: 26 jan. 2011;Wikipedia. Judicial functions of the House of Lords. Disponível em: http: / / en.wikipedia.org/wiki/Judicial_functions_of_the_ House_of_Lords. Acesso em: 26 jan. 2011; Wikipedia. Supreme Court of the United Kingdom. Disponível em: http://en.wikipedia.org/wiki/Supreme_Court_of_the_United_Kingdom. Acesso em: 26 jan. 2011; Conselho Da Europa. Convenção para a Protecção dos Direitos do Homem e das Liberdades Fundamentais, com as modificações introduzidas pelos Protocolos ns. 11 e 14, acompanhada do Protocolo adicional e dos Protocolos ns. 4, 6, 7 e 13. Disponível em: http://www.echr.coe.int/NR/rdonlyres/7510566B-AE54-44B9-A163-912EF12B8BA4/0/ POR_CONV.pdf. Acesso em: 5 jan. 2011, redação da tradução oficial, em português europeu, ajustada por nós ao português brasileiro.

35 Conselho Da Europa. European Court of Human Rights (Grand Chamber). Goodwin v. the United Kingdom (Application n. 17488/90). Strasbourg, 27 March 1996. Disponível em: 
julgado no qual o órgão maior do TEDH atinou, igualmente, com outro acórdão da Câmara dos Lordes, Secretary of State for Defense v. Guardian Newspapers [1985] AC 339.

Ambos os julgados da Câmara dos Lordes esposaram o entendimento de que, no interesse da justiça, uma pessoa tem o dever de declinar a identidade do autor de ilícito, caso aquela tenha se envolvido com a circunstância em que se deu a prática do ato, mesmo que não tenha sido seu autor nem partícipe, a exemplo do jornalista que produz reportagem alicerçada em fonte anônima e esta, ao lhe repassar determinadas informações, violou sigilo profissional ou infringiu o dever funcional de guardar sigilo sobre os assuntos de seu ambiente de trabalho.

Naquela oportunidade, a Grande Câmara ponderou a relevância de que conceitos legais que confiram certa margem discricionária à interferência do Poder Público no exercício de determinado direito recebam construções judiciais que tenham o condão de tornar mais claro ao destinatário da lei em que consistiria o tipo ilícito delineado pelo legislador (Goodwin v. the United Kingdom, § 33). ${ }^{36}$

É que não bastaria insculpir em lei formal o tipo do ilícito: seria necessário que o destinatário da norma pudesse, antes de cogitar a prática da conduta prevista no tipo, ter condições razoáveis de compreender, mediante a leitura do dispositivo legal e, se necessário, eventual assessoramento jurídico, o caráter ilícito da conduta proscrita, de modo que a redação do texto legal propiciasse um grau de precisão que tornasse possível ao destinatário da norma antever os possíveis desdobramentos jurídicos da conduta cogitada (Goodwin v. the United Kingdom, § 31). ${ }^{37}$

Ao apreciar recurso contrário ao acórdão da Terceira Seção do TEDH em Sanoma Uitgevers B.V. v. The Netherlands, ${ }^{38}$ a Grande Câmara da Corte de Estrasburgo, em 14 de setembro de 2010, reiterou tal ponderação ( $\S$ $81^{39}$ ) em termos mais sucintos, ao ressaltar que a lei deve ser adequada-

http: / / www.echr.coe.int/ECHR. Acesso em: 6 jan. 2011.

36 Ibidem, loc. cit.

37 Ibidem, loc. cit.

38 Conselho Da Europa. European Court of Human Rights (Grand Chamber). Sanoma Uitgevers B.V. v. The Netherlands (Application n. 38224/03). Strasbourg, 14 September 2010. Disponível em: http: / /www.echr.coe.int/ECHR. Acesso em: 6 jan. 2011.

39 Ibidem, loc. cit. 
mente acessível (à compreensão do destinatário da norma) e previsível (em seus efeitos), para que, assim, o indivíduo possa se pautar pelas balizas extraídas de tal preceito.

Acrescentou, baseada na jurisprudência remansosa do TEDH e em repulsa a normas que proporcionem poderes incondicionados aos agentes públicos, que a lei deve indicar, com clareza suficiente, o escopo da discricionariedade cometida à autoridade estatal competente para interferir na esfera jurídica alheia e os meios de exercício dos correspondentes poderes (Grande Câmara, Sanoma Uitgevers B.V.v. The Netherlands, § 82)..$^{40}$

Esplendeu a exigibilidade, principalmente em casos de tutelas de urgência (em que a autoridade a pleitear o descerramento do sigilo jornalístico, premida pelo tempo, não tem, por vezes, a oportunidade de alinhavar uma motivação mais minuciosa), de que órgão externo ao Poder Executivo e às demais partes, na qualidade de instância revisora (órgão de âmbito judicial ou extrajudicial), faça, de maneira objetiva e imparcial, o controle do ato estatal de quebra do sigilo jornalístico.

A Grande Câmara, ainda em Sanoma Uitgevers B.V.v.The Netherlands ( $\S \S$ 94, 100 e $101^{41}$ ), ao se reportar ao critério da prescrição por lei, referiuse também à qualidade da lei: embora a quebra do sigilo da(s) fonte(s) jornalística(s) contasse, in casu, com previsão em lei formal (Código de Processo Penal), a qualidade da lei se revelara deficiente ou insuficiente aos olhos do órgão maior do TEDH, porque, no âmbito do Estado contratante demandado (o Reino dos Países Baixos), a função de órgão revisor da ordem de quebra do sigilo jornalístico, depois da entrada em vigência do art. 96a do Estatuto Processual Penal neerlandês ("holandês"), ${ }^{42}$ passou a ser incumbência de membro do Ministério Público, o qual, como parte interessada na persecução penal e por não constituir órgão do Poder

40 Ibidem, loc. cit.

41 Ibidem, loc. cit.

42 “Os Países Baixos são comumente conhecidos em português (e também noutros idiomas) como Holanda, todavia esta é uma denominação considerada imprópria... pois 'Holanda’ é apenas uma das regiões dos Países Baixos, hoje formada pelas províncias da Holanda Setentrional e Holanda Meridional". Cf. Wikipédia. Holanda (topônimo). Disponível em: http://pt.wikipedia.org/wiki/Holanda_(topônimo). Acesso em: 25 dez. 2010. 
Judiciário, não poderia assegurar a necessária independência no controle, como instância revisora, da referida ordem. ${ }^{43}$

Destarte, em Sanoma Uitgevers B.V.v. The Netherlands, a Grande Câmara da Corte de Estrasburgo reformou o decisum da Terceira Seção, a qual, para fins de comprovação da prescrição por lei, havia reputado suficiente o disposto no art. 96a do CPP do Reino dos Países Baixos ( $§ 51$ a 52) e, ao final, não vislumbrara ofensa ao art. 10 da Convenção Europeia dos Direitos Humanos ${ }^{44}(\S 63) .^{45}$

Naquele aresto, a Grande Câmara do Tribunal Europeu dos Direitos Humanos frisou que aferir se uma interferência estatal no exercício de direito fundamental está de acordo com a lei ou prescrita por lei significa ter presente não apenas o Direito Legislado como também atos administrativos com conteúdo de lei, inclusive atos normativos emanados de órgãos de fiscalização profissional, bem assim a jurisprudência consolidada (Grande Câmara, Sanoma Uitgevers B.V. v. The Netherlands, § 8346). Preconizou, em suma, o acolhimento da acepção de lei em sentido material ou substantivo, em detrimento da adoção da acepção de lei stricto sensu ou em sentido meramente formal (mesmo parágrafo). ${ }^{47}$

Em mesma direção se situou a Segunda Seção do TEDH em Ernst et Autres c. Belgique $e^{48}$, de 15 de julho de 2003, ao lembrar que a jurisprudência

43 Conselho Da Europa. European Court of Human Rights (Grand Chamber). Sanoma Uitgevers B.V. v. The Netherlands (Application n. 38224/03). Strasbourg, 14 September 2010. Disponível em: http: / / www.echr.coe.int/ECHR. Acesso em: 6 jan. 2011.

44 Conselho Da Europa. European Court of Human Rights (Third Section). Sanoma Uitgevers B.V.v. The Netherlands (Application n. 38224/03). Strasbourg, 31 March 2009. Disponível em: http: / / www.echr.coe.int/ECHR. Acesso em: 6 jan. 2011.

45 Ibidem, loc. cit.

46 Ibidem, loc. cit.

47 Ibidem, loc. cit.

Lei formal no sentido de integrar o Direito Legislado, por ter se submetido ao devido processo legislativo. Lei em sentido formal ou orgânico: “... ato do órgão investido, constitucionalmente, na função legislativa.” Lei em sentido material: “... norma geral, abstrata e obrigatória” a ordenar a coletividade. O ato estatal pode ser lei do ponto de vista formal (ter "forma de lei”) e/ou material (possuir "a substância do ato legislativo", sendo "regra geral e impessoal de conduta, imperativamente imposta para o ordenamento da vida coletiva"). $C f$. Fagundes, Miguel Seabra, O controle dos atos administrativos pelo Poder Judiciário, 7a. ed., Rio de Janeiro, 2005, p. 25-26.

48 Conselho da Europa. Cour européenne des Droits de l'Homme (deuxième section). Ernst et Autres v. Belgique (Requête n. 33400/96). Strasbourg, 15 juillet 2003. Disponível em: 
iterativa da Corte de Estrasburgo enxerga a lei em sentido material e não formal (§ 96), a abarcar, no campo de incidência da acepção de lei, o Direito construído com base na interpretação legal feita pelos órgãos judiciários competentes (§ 96).

\section{O critério da finalidade legítima}

Para fins de quebra do sigilo da(s) fonte(s) jornalística(s), finalidade(s) legítima(s) pode $(\mathrm{m})$ dizer respeito (a) ao propósito de coibir a divulgação midiática de informações confidenciais de uma sociedade empresária (Grande Câmara, Goodwin v. the United Kingdom, ${ }^{49} \S \S 11$ e 35), (b) ao intento de prevenir a desordem e/ou crime (Quarta Seção, Roemen and Schmit v. Luxembourg, ${ }^{50} \S 50$; Terceira Seção, Sanoma Uitgevers B. V. v. The Netherlands, ${ }^{51} \S 53$; Terceira Seção, Voskuil v. The Netherlands, ${ }^{52} \S \S 54 \mathrm{e}$ 56), (c) ao duplo desiderato de proteger direitos alheios e evitar o vazamento de informações fornecidas em caráter confidencial (Quarta Seção, Financial Times Ltd and Others v. The United Kingdom, § 58), ${ }^{53}(d)$ de prevenir desordem ou crime e salvaguardar direitos alheios (Primeira Seção, Nordisk Film \&TV A/S v. Denmark), ${ }^{54}$ (e) ao triplo fim de impedir a divulgação

http://www.echr.coe.int/ECHR. Acesso em: 6 jan. 2011.

49 Conselho Da Europa. European Court of Human Rights (Grand Chamber). Goodwin v. the United Kingdom (Application n. 17488/90). Strasbourg, 27 March 1996. Disponível em: http: / / www.echr.coe.int/ECHR. Acesso em: 6 jan. 2011.

50 Conselho Da Europa. European Court of Human Rights (Fourth Section). Roemen and Schmit v. Luxembourg (Application n. 51772/99). Strasbourg, 25 February 2003. Disponível em: http://www.echr.coe.int/ECHR. Acesso em: 6 jan. 2011.

51 Conselho Da Europa. European Court of Human Rights (Third Section). Sanoma Uitgevers B.V.v. The Netherlands (Application n. 38224/03). Strasbourg, 31 March 2009. Disponível em: http://www.echr.coe.int/ECHR. Acesso em: 6 jan. 2011.

52 Conselho Da Europa. European Court of Human Rights (Third Section). Voskuil v. The Netherlands (Application n. 64752/01). Strasbourg, 22 November 2007. Disponível em: http: / / www.echr.coe.int/ECHR. Acesso em: 6 jan. 2011.

53 Conselho Da Europa. European Court of Human Rights (Fourth Section). Financial Times Ltd and Others v. The United Kingdom (Application n. 821/03). Strasbourg, 15 December 2009. Disponível em: http://www.echr.coe.int/ECHR. Acesso em: 6 jan. 2011.

54 Conselho Da Europa. European Court of Human Rights (First Section). Nordisk Film \& TV A/S v. Denmark (Application n. 40485/02). Strasbourg, 8 December 2005. Disponível em: 
de informações confidenciais, proteger a reputação alheia e assegurar a autoridade e a imparcialidade do Poder Judiciário (Segunda Seção, Ernst et Autres c. Belgique, § 98), ${ }^{55}$ e (f) de visar à defesa da ordem pública, à prevenção de infrações penais e da divulgação de informações confidenciais e à proteção da reputação alheia (Segunda Seção, Tillack c. Belgique, § 59). ${ }^{56}$

Ao examinar as alegações do respectivo Estado contratante de que houve finalidade(s) legítima(s) a nortear(em) determinado procedimento estatal de quebra de sigilo jornalístico, o Tribunal Europeu dos Direitos Humanos, por vezes, não perscruta a presença de todas as finalidades invocadas pelo polo passivo, bastando-lhe, para reputar contemplada tal exigência, concluir que se encontra comprovada nos autos parcela das finalidades aludidas pelo Estado requerido:

(a) Em Goodwin v. the United Kingdom, ${ }^{57}$ o Estado contratante arguiu os propósitos de proteger o sigilo empresarial e de promover a prevenção criminal (§ 35). ${ }^{58}$ A Grande Câmara da Corte de Estrasburgo, ao acolher o primeiro argumento, dispensou a si mesma de proceder à análise do segundo argumento $(\S 36) .{ }^{59}$

(b) E, em Voskuil v. The Netherlands, ${ }^{60}$ o Estado contratante mencionou os fins de proteger a reputação ou os direitos alheios (notadamente, a integridade moral do Poder Judiciário dos Países Baixos e da Polícia de Amsterdã), de resguardar a segurança pública e de efetuar a prevenção de crime ou de desordem (§ 54). ${ }^{61}$ A Terceira Seção do TEDH se ateve a aceitar

http: / / www.echr.coe.int/ECHR. Acesso em: 6 jan. 2011.

55 Conselho Da Europa. Cour européenne des Droits de l'Homme (deuxième section). Ernst et Autres v. Belgique (Requête n. 33400/96). Strasbourg, 15 juillet 2003. Disponível em: http: / / www.echr.coe.int/ECHR. Acesso em: 6 jan. 2011.

56 Conselho Da Europa. Cour européenne des Droits de l'Homme (deuxième section). Tillack c. Belgique (Requête n. 20477/05). Strasbourg, 15 juillet 2003. Disponível em: http: / / www.echr.coe.int/ECHR. Acesso em: 6 jan. 2011.

57 Conselho Da Europa. European Court of Human Rights (Grand Chamber). Goodwin v. the United Kingdom (Application n. 17488/90). Strasbourg, 27 March 1996. Disponível em: http: / / www.echr.coe.int/ECHR. Acesso em: 6 jan. 2011.

58 Ibidem, loc. cit.

59 Ibidem, loc. cit.

${ }^{60}$ Conselho Da Europa. European Court of Human Rights (Third Section). Voskuil v. The Netherlands (Application n. 64752/01). Strasbourg, 22 November 2007. Disponível em: http: / / www.echr.coe.int/ECHR. Acesso em: 6 jan. 2011.

${ }^{61}$ Ibidem, loc. cit. 
o argumento da prevenção criminal, sem se posicionar, portanto, acerca das demais finalidades invocadas pelo polo passivo ( $§ 56) .{ }^{62}$

Já em Financial Times Ltd and Others v. The United Kingdom ( $\$ 58),{ }^{63}$ no qual o Estado contratante, em sua peça de defesa, indicou os fitos de (1) resguardar os direitos alheios, de (2) se acautelar contra o vazamento de informações repassadas de forma confidencial e (3) de prevenir a prática delituosa, a Quarta Seção da referida Corte Europeia, além de abraçar os dois primeiros argumentos, analisou a terceira justificativa, rejeitando-a, porque a prevenção criminal, atribuição típica do Poder Público, não se aplicava ao caso vertente, porquanto, in casu, a quebra do sigilo jornalístico tinha sido requerida, não por órgão público, mas por entidade privada não estatal (sociedade empresária belga, a cervejaria Interbrew, grupo econômico sucedido, na atualidade, pela Anheuser-Busch InBev N. V. - AB $\left.\operatorname{In} B \mathrm{~V}^{64}\right)$, que anelara, ao solicitar tal provimento estatal, identificar as pessoas que forneceram a órgãos de comunicação social informações sigilosas cuja divulgação midiática havia lhe ocasionado consideráveis prejuízos financeiros $(\S \S 58$ e 16$) .{ }^{65}$

\section{O critério da necessidade}

Ao avaliar se dada flexibilização no resguardo do sigilo jornalístico afrontou o art. 10 da CEDH, a Corte de Estrasburgo tende a ser mais rigorosa ao final do julgamento do mérito, quando da análise estribada justamente no último critério, por meio do qual esquadrinha se uma interferência estatal se demonstra necessária em uma sociedade democrática.

62 Ibidem, loc. cit.

63 Conselho Da Europa. European Court of Human Rights (Fourth Section). Financial Times Ltd and Others v. The United Kingdom (Application n. 821/03). Strasbourg, 15 December 2009. Disponível em: http://www.echr.coe.int/ECHR. Acesso em: 6 jan. 2011.

${ }^{64}$ Wikipedia. Anheuser-Busch InBev. Disponível em: http://en.wikipedia.org/wiki/Anheuser-Busch_InBev. Acesso em: 26 jan. 2011.

65 Conselho Da Europa. European Court of Human Rights (Fourth Section). Financial Times Ltd and Others v. The United Kingdom (Application n. 821/03). Strasbourg, 15 December 2009. Disponível em: http://www.echr.coe.int/ECHR. Acesso em: 6 jan. 2011. 
Em Goodwin v. the United Kingdom, ${ }^{66}$ de 27 de março de 1996, a Grande Câmara do Tribunal Europeu dos Direitos Humanos, ao fundear os alicerces da visão do TEDH sobre o descobrimento do manto do sigilo $\mathrm{da}(\mathrm{s})$ fonte(s) jornalística(s), postulou estas balizas:

(a) Restringe-se às circunstâncias excepcionais, isto é, adstringe-se às situações em que estão em jogo interesses públicos ou privados de cunho vital $(\S 37) .{ }^{67}$

(b) A margem discricionária para a autoridade nacional aferir se existe, na circunstância com a qual se depara, uma necessidade social premente de se relativizar o sigilo jornalístico encontra-se circunscrita pelo interesse da sociedade democrática de assegurar e manter a liberdade de imprensa, aspiração coletiva que se reveste de peso considerável, ao se sopesar se, em dado contexto concreto, a restrição ao caráter inviolável do sigilo $\mathrm{da}(\mathrm{s})$ fonte(s) jornalística(s) foi proporcional à finalidade legítima perseguida pelo Estado que assim procedeu $(\S 40) .{ }^{68}$

(c) Incumbe à Corte de Estrasburgo o múnus de verificar se o Estado contratante impôs, de fato, temperamentos à inviolabilidade do sigilo jornalístico, e, em caso afirmativo, se, ao fazê-lo, estribou-se em motivos relevantes e suficientes ( $\$ 40)$, de tal sorte que tenha existido um razoável nexo de proporcionalidade entre, de um lado, a finalidade legítima que impeliu o Estado demandado a emitir ordem de quebra de sigilo $\mathrm{da}(\mathrm{s})$ fonte(s) jornalística(s) e, de outra banda, os meios adotados pelo aparelho estatal a fim de alcançar esse desiderato ${ }^{69}$.

No referido julgamento, a Grande Câmara do TEDH conclui que foi excessiva a decisão judicial britânica de impor a jornalista a obrigação de declinar a fonte que lhe revelou o plano corporativo confidencial da sociedade empresária (Tetra $L t d$ ) que requereu a quebra do sigilo jornalístico, com vistas a conter o vazamento de tais informações (Goodwin v. the United Kingdom, $\S \S 12$ e 46). ${ }^{70}$

66 Conselho Da Europa. European Court of Human Rights (Grand Chamber). Goodwin v. the United Kingdom (Application n. 17488/90). Strasbourg, 27 March 1996. Disponível em: http: / / www.echr.coe.int/ECHR. Acesso em: 6 jan. 2011.

${ }^{67}$ Ibidem, loc. cit.

68 Ibidem, loc. cit.

69 Ibidem, loc. cit.

70 Ibidem, loc. cit. 
Ao assim decidir, o órgão maior da Corte de Estrasburgo levou em conta que à época da quebra judicial do sigilo da respectiva fonte jornalística já se encontrava proibida, pela Justiça britânica, a divulgação de tais informações pela mídia, tornando-se, por isso, despiciendo o fornecimento das anotações do jornalista sobre conversação telefônica por meio das quais se extrairia a identidade de fonte que subsidiou reportagem sobre o plano corporativo confidencial de empréstimo financeiro que Tetra Ltd pretendia contrair, para equilibrar suas finanças. A ausência da necessidade da quebra de fonte jornalística foi constatada, in casu, pela Grande Câmara do Tribunal Europeu dos Direitos Humanos, considerando, a par dessa finalidade (de conter o vazamento de informações), outros propósitos que também impeliram Tetra Ltd a solicitar as mencionadas anotações, isto é, os fins de (a) viabilizar ação indenizatória e (b) desmascarar o empregado ou colaborador que agiu de maneira desleal (Goodwin v. the United Kingdom, $\S \S 10$ a 16, 42 e 45 a 46). ${ }^{71}$

Ao esposar síntese da construção pretoriana acerca do sigilo jornalístico inaugurada em Goodwin v. the United Kingdom, a Quarta Seção do Tribunal Europeu dos Direitos Humanos, em Roemen and Schmit v. Luxembourg, ${ }^{72}$ de 25 de fevereiro de 2003, consignou 3 (três) requisitos (§ 51) para se esclarecer se a flexibilização do sigilo da(s) fonte(s) jornalística(s) foi necessária em uma sociedade democrática: (1) se a interferência contemplou necessidade social premente, (2) se foi proporcional à finalidade legítima perseguida e (3) se as razões declinadas pelas autoridades nacionais, ao justificarem as medidas restritivas, foram relevantes e suficientes.

Em tal precedente, a Quarta Seção teve por ponderável a relevância dos motivos elencados pelo Estado contratante, porém rejeitou a suficiência de tais razões para justificar mandados de busca e apreensão realizados na residência e no ambiente de trabalho de jornalista, com o propósito de apurar a identidade de agentes públicos que forneceram ao autor as informações sigilosas baseadas nas quais redigiu matéria jornalística a noticiar fraude tributária supostamente praticada por Minis-

71 Ibidem, loc. cit.

72 Conselho Da Europa. European Court of Human Rights (Fourth Section). Roemen and Schmit v. Luxembourg (Application n. 51772/99). Strasbourg, 25 February 2003. Disponível em: http://www.echr.coe.int/ECHR. Acesso em: 6 jan. 2011. 
tro do Governo do Grão-Ducado de Luxemburgo (Roemen and Schmit v. Luxembourg, $\S \S 55,56$ e 59)..$^{73}$

Articulando com mais minudência tais balizas, a Terceira Seção da Corte de Estrasburgo, em Sanoma Uitgevers B.V.v. The Netherlands, ${ }^{74}$ de 31 de março de 2009, reconheceu a margem discricionária para os Estados signatários da Convenção Europeia dos Direitos Humanos analisarem se, em determinada circunstância, faz-se presente uma necessidade social premente que torne, com o perdão da redundância, necessária em uma sociedade democrática, a quebra do sigilo da(s) fonte(s) jornalística(s), ao mesmo tempo que salientou a competência do Tribunal Europeu de Direitos Humanos, como reflexo da supervisão europeia sobre a atuação dos Estados contratantes, de proferir a decisão final nos casos levados à sua apreciação (inclusive na qualidade de instância revisora de atos decisórios proferidos pelo respectivo Poder Judiciário nacional), relativamente à controvérsia acerca da congruência de tal medida estatal com a proteção à liberdade de expressão de que cuida o art. 10 da indicada Convenção ( $\$ 54$, alínea $a)$, tendo em perspectiva não apenas verificar se a atuação discricionária do Estado demandado foi razoável, cuidadosa e de boa-fé como também julgar o meritum causae com esteio em uma visão ampla do caso concreto analisado, ou seja, efetuar o exame da interveniência estatal "à luz do caso como um todo" (Sanoma Uitgevers B.V. v. The Netherlands, $\S 54$, alínea $b) .^{75}$

Enfatizou que, amparado nas informações prestadas pelo Estado contratante, cabe ao Tribunal Europeu dos Direitos Humanos averiguar se as autoridades nacionais avaliaram de forma adequada os fatos relevantes e se procederam em harmonia com o plexo normativo do art. 10 da $\mathrm{CEDH}$, o que significa aferir se houve motivos suficientes e relevantes e se a medida adotada foi proporcional à finalidade legítima em mira (Sanoma Uitgevers B.V.v. The Netherlands, $§ 54$, alínea c). ${ }^{76}$

73 Ibidem, loc. cit.

74 Conselho Da Europa. European Court of Human Rights (Third Section). Sanoma Uitgevers B.V.v. The Netherlands (Application n. 38224/03). Strasbourg, 31 March 2009. Disponível em: http: / / www.echr.coe.int/ECHR. Acesso em: 6 jan. 2011.

75 Ibidem, loc. cit.

76 Ibidem, loc. cit. 
Recordou que os temperamentos à inviolabilidade do sigilo da(s) fonte(s) jornalística(s) somente se justificam quando existe um interesse público cuja densidade, na situação in concreto, sobreponha-se à importância do sigilo jornalístico em uma sociedade democrática e ao potencial efeito inibitório (chilling effect ou effet inhibant) da quebra do sigilo sobre o exercício da liberdade de imprensa (Sanoma Uitgevers B.V. v. The Netherlands, $\S 54$, alínea d). ${ }^{77}$

Percebe-se, assim, a preferência do Tribunal Europeu dos Direitos Humanos por intervenções estatais tópicas e sua oposição a medidas instrutórias que não se revelem indispensáveis ou que se denotem exorbitantes, a exemplo de devassas (materializadas, por vezes, por intermédio de buscas e apreensões indiscriminadas).

Ilustrativo, nesse aspecto, o caso Roemen and Schmit v. Luxembourg, ${ }^{78}$ no qual a Quarta Seção do TEDH teve por excessiva a quebra de sigilo jornalístico levada a efeito via buscas e apreensões realizadas nos ambientes profissional e residencial de jornalista, destinadas a apreender qualquer material que, por ventura, contribuísse para identificar eventuais servidores públicos que serviram de fontes a artigo jornalístico a respeito da condenação de Ministro de Estado por fraude fiscal, reputando tais diligências probatórias mais drásticas que uma requisição judicial de que fosse declinada a identidade de fontes jornalísticas $\left(\S \S 8^{\circ}\right.$ a $13,15,17$, 52, 57 e 58).

Nessa senda, a Primeira Seção do Tribunal Europeu dos Direitos Humanos, em Nordisk Film \&TV A / S v. Denmark, aos 8 de dezembro de 2005, prestigiou acórdão da Suprema Corte dinamarquesa (Højesteret) que determinou à produtora de TV o fornecimento da parcela de gravações não editadas de reportagem sobre uma associação dinamarquesa de pedófilos, ou seja, no caso vertente, a Corte de Estrasburgo chancelou aresto do Pretório Excelso da Dinamarca, haja vista que este, ao anuir com a quebra do sigilo jornalístico, restringiu o campo de incidência de tal medida instrutória à parte das gravações não editadas atinentes a pedófilo à época investigado pela Polícia dinamarquesa e a menor indiano

77 Ibidem, loc. cit.

78 Conselho Da Europa. European Court of Human Rights (Fourth Section). Roemen and Schmit v. Luxembourg (Application n. 51772/99). Strasbourg, 25 February 2003. Disponível em: http://www.echr.coe.int/ECHR. Acesso em: 6 jan. 2011. 
vítima daquele, bem assim à parcela das anotações do jornalista autor da matéria específicas sobre essa circunstância, sem que fosse exposta a identidade de terceiros (vítima, policial e mãe do administrador do hotel em que ocorrera fatos relatados na reportagem) que aceitaram colaborar com o jornalista sob a condição de que suas identidades não fossem reveladas. ${ }^{79}$

Medidas instrutórias indiscriminadas, além de consistirem em intervenções desnecessárias na esfera jurídica dos jornalistas e de terceiros que com estes colaboram sob a condição de anonimato ou de sigilo, acarretam efeito inibitório excessivo sobre jornalistas, órgãos de comunicação social e eventuais fontes jornalísticas.

Com efeito, a Terceira Seção da Corte de Estrasburgo, em Voskuil v. The Netherlands ${ }^{80}$ (§ 70), de 22 de novembro de 2007, pontificou que medidas de quebra de sigilo jornalístico de longo alcance têm o condão de desencorajar pessoas que possuem informações verdadeiras e precisas de informarem aos meios de comunicação social a prática de ilícitos graves, como os que concerniam àqueles autos (tráfico de armas em Amsterdã).

Em outros dizeres, na circunstância acima, a Terceira Seção do Tribunal Europeu dos Direitos Humanos enxergou a intervenção estatal como prescrita por lei (encastoada no art. 294 do Estatuto Processual Penal dos Países Baixos) e direcionada à finalidade legítima (prevenção criminal), porém não a reputou necessária em uma sociedade democrática, ao divisar a prisão provisória de jornalista, durante 17 (dezessete) dias, como medida judicial de longo alcance a inibir fontes jornalísticas de for-

79 Na ocasião, assentou a Primeira Seção que a exceção ao dever de testemunhar visa a proteger pessoas que concordam em participar de matérias jornalísticas sob a condição de que suas identidades sejam mantidas em sigilo. No mesmo julgado, ponderou o TEDH que pessoas filmadas sem assim consentirem ou sem estarem cientes disso (porque filmadas por câmera escondida) não seriam fontes jornalísticas em sentido estrito ("cannot be regarded as sources of journalistic information in the traditional sense”), porém consubstanciariam material de pesquisa do jornalista que as filmou. Cf. Conselho Da Europa. European Court of Human Rights (First Section). Nordisk Film \& TV A/S v. Denmark (Application n. 40485/02). Strasbourg, 8 December 2005. Disponível em: http://www.echr.coe.int/ECHR. Acesso em: 6 jan. 2011.

80 Conselho Da Europa. European Court of Human Rights (Third Section). Voskuil v. The Netherlands (Application n. 64752/01). Strasbourg, 22 November 2007. Disponível em: http: / / www.echr.coe.int/ECHR. Acesso em: 6 jan. 2011. 
necerem à imprensa informações precisas e verdadeiras sobre ilícitos da espécie de que cuidavam aqueles autos - tráfico de armas (Voskuil v. The Netherlands, $\S \S 50$ a 56, 60, 71 e 72). ${ }^{81}$

Nesse lanço, a Segunda Seção doTEDH, em Ernst et Autres c. Belgique, ${ }^{82}$ de 15 de julho de 2003, repeliu buscas e apreensões em massa (ocorridas em redações e residências de jornalistas) destinadas à apuração de vazamento, por magistrados, de informações a órgãos de comunicação social sobre processos criminais sensíveis, enxergando em tais medidas instrutórios atos estatais mais onerosos à liberdade de imprensa do que a identificação pontual de fontes jornalísticas, além de refutar, na circunstância em tela, o argumento da ausência de medidas instrutórias alternativas menos gravosas e, por outro lado, destacar a insuficiência dos motivos invocados pelo Estado contratante para justificar devassa de

${ }^{81}$ No contexto de Voskuil v. The Netherlands (caso ora em comento), jornalista se recusara a revelar a identidade de fonte jornalística em que se baseara para escrever dois artigos (publicados em jornal) relativos à investigação criminal sobre tráfico de armas. Fora mantido em prisão cautelar, de modo que assim aceitasse declinar sua fonte ( $\S 3^{\circ}, 7^{\circ}$ a 16 e 60$)$. O jornalista fundamentara sua recusa no juízo de prognose de que, caso identificasse sua fonte, inviabilizar-se-ia o exercício de sua profissão, porquanto, dali em diante, nenhuma outra pessoa se disporia a lhe fornecer informação sob a condição de manter em sigilo a própria identidade ( $\S \S 12$ e 19). Ambas as matérias jornalísticas, estribadas em informações dadas por policial envolvido na operação objeto dos 2 (dois) artigos, refutaram a explicação oficial de que as provas que resultaram, para 3 (três) pessoas, em longas penas privativas de liberdade decorreram da descoberta ao acaso de arsenal de armas escondido em flat de Amsterdã, quando a Polícia amesterdanesa abrira o imóvel cujos ocupantes se encontravam ausentes, a fim de conter vazamento d'água a pedido do síndico do condomínio. Alegou o jornalista que o vazamento fora provocado pela Polícia, com o fito de tornar juridicamente justificável a entrada da autoridade policial naquele recinto. Após a versão divulgada pelo jornalista ser rechaçada pelo depoimento de 10 (dez) policiais, a Corte de Apelação de Amsterdã (Gerechtshof Amsterdam) determinou a soltura do referido profissional do Jornalismo, por considerar que tais provas testemunhais esvaziaram a credibilidade da versão dos fatos abraçada por aquele. Antes de assim decidir, entendera a Corte de Apelação que o jornalista deveria identificar sua fonte, uma vez que seria a única testemunha que poderia esclarecer se houve realmente erro judiciário, e, caso suas alegações se mostrassem, de fato, verídicas, a eventual ilicitude do meio empregado para a colheita dos elementos probatórios da condenação prejudicaria a legalidade das penas impostas aos acusados de tráfico Ilícito de armas e vulneraria a integridade moral da Polícia e da Justiça locais ( $\S \S 7^{\circ}$ a 24). Cf. ibidem, loc. cit.

82 Conselho Da Europa. Cour européenne des Droits de l'Homme (deuxième section). Ernst et Autres v. Belgique (Requête n. 33400/96). Strasbourg, 15 juillet 2003. Disponível em: http: / / www.echr.coe.int/ECHR. Acesso em: 6 jan. 2011. 
tamanha envergadura (envolvendo, alegadamente, 160 policiais), isto é, notou a falta de uma razoável proporcionalidade entre as diligências probatórias implementadas e as finalidades legítimas a que serviam ( $\S$ 101 a 105$).{ }^{83}$

Outro precedente emblemático no tocante à repelência da Corte de Estrasburgo a amplas medidas instrutórias invasivas do sigilo jornalístico radica no caso Tillack c. Belgique, julgado pela Segunda Seção do TEDH em 27 de novembro de 2007, quando salientou a demasia de medidas de busca e apreensão efetuadas pelo Poder Judiciário da Bélgi$\mathrm{Ca}^{84}$ na residência e no ambiente de trabalho de jornalista alemão que, arrimado em fonte jornalística sigilosa (funcionário público da União Europeia - UE), escrevera dois artigos publicados na revista Stern (tradicional semanário tedesco) por meio dos quais noticiou, na primeira matéria jornalística, irregularidades no âmbito de instituições comunitárias, e, após, na segunda matéria jornalística, levou ao conhecimento público o advento de procedimentos internos, deflagrados no seio da Administração Pública da UE, a apurarem a ocorrência de tais fatos ( $\S \S$ $6^{\circ}$ a $9^{\circ}$ e 66 a 68$) .{ }^{85}$

Com razão, a Quarta Seção doTEDH, em FinancialTimes Ltd and Others v. The United Kingdom ${ }^{86}$ (§ 63), de 15 de dezembro de 2009, observa que o efeito inibitório decorrente da quebra do sigilo bancário não incide somente sobre a pessoa que é, naquele caso concreto, a fonte do jornalista (efeito dissuasório, ante o risco e o temor de que sua identidade seja revelada) mas também sobre a reputação do respectivo órgão de comunicação social (o fato de ser o órgão em relação ao qual foi exigida a identificação de determinada fonte teria efeito dissuasório sobre outras pessoas - inclusive do público - que, por ventura, tivessem a eventual predispo-

83 Ibidem, loc. cit.

${ }^{84}$ Bruxelas, capital da Bélgica, assim como Luxemburgo (capital do Grão-Ducado de Luxemburgo) e Estrasburgo (Nordeste da França), é uma das principais cidades em que se concentra a estrutura administrativa da União Europeia.

85 Conselho da Europa. Cour Européenne des Droits de l'Homme (deuxième section). Tillack c. Belgique (Requête n. 20477/05). Strasbourg, 15 juillet 2003. Disponível em: http: / / www.echr.coe.int/ECHR. Acesso em: 6 jan. 2011.

${ }^{86}$ Conselho da Europa. European Court of Human Rights (Fourth Section). Financial Times Ltd and Others v. The United Kingdom (Application n. 821/03). Strasbourg, 15 December 2009. Disponível em: http: / /www.echr.coe.int/ECHR. Acesso em: 6 jan. 2011. 
sição ou o potencial de lhe fornecer, de modo sigiloso, informações de interesse público, e, por receio de terem suas identidades posteriormente descobertas, mudariam de ideia, optando por não subsidiarem tais informações ao respectivo órgão de comunicação social), além de frustrar a parcela do público que almeja ter acesso a informações de interesse público repassadas por fontes anônimas. Mesma observação registrada em 14 de setembro de 2010, pela Grande Câmara da Corte de Estrasburgo (Sanoma Uitgevers B.V.v. The Netherlands, §89) ${ }^{87}$.

Assinalou a Quarta Seção do TEDH, no acórdão acima citado (Financial Times Ltd and Others v. The United Kingdom, $\S$ 63, in fine ${ }^{88}$ ), que a conduta da fonte (a licitude ou ilicitude com que se houve uma pessoa, ao divulgar informações à imprensa) nunca deve ser o fator decisivo para se determinar a necessidade de uma ordem de quebra de sigilo jornalístico: ainda que relevante, convém que figure como mais um fator, dentre outros, a ser considerado, ao se avaliar o coeficiente de proporcionalidade da medida estatal impugnada.

No precedente em testilha, ressaltou-se a presença de efeito inibitório quando o jornalista é compelido a colaborar com a identificação de fontes anônimas, independente dos documentos requisitados pela autoridade judiciária contemplarem tal finalidade de modo direto ou indireto (Financial Times Ltd and Others v. The United Kingdom, § 70). ${ }^{89}$

Diante do efeito inibitório da quebra do sigilo jornalístico, a Quarta Seção do Tribunal Europeu dos Direitos Humanos conferiu, no julgado em epígrafe, primazia à proteção da fonte jornalística, em detrimento do interesse da sociedade empresária prejudicada (cervejaria Interbrew) de que fosse identificada a fonte jornalística da qual promanara o vazamento de informações concernentes a tratativas visando à incorporação, por aquela, de concorrente sul-africana (South African Breweries Ltd - SAB), mesmo tendo a Corte de Estrasburgo levado em conta, in

87 Conselho da Europa. European Court of Human Rights (Grand Chamber). Sanoma Uitgevers B.V.v. The Netherlands (Application n. 38224/03). Strasbourg, 14 September 2010. Disponível em: http://www.echr.coe.int/ECHR. Acesso em: 6 jan. 2011.

88 Conselho da Europa. European Court of Human Rights (Fourth Section). Financial Times Ltd and Others v. The United Kingdom (Application n. 821/03). Strasbourg, 15 December 2009. Disponível em: http: //www.echr.coe.int/ECHR. Acesso em: 6 jan. 2011.

${ }^{89}$ Ibidem, loc. cit. 
casu, que a aspiração da mencionada entidade privada, ao requerer tal disclosure, concernia aos fins de evitar danos vindouros, provenientes de novos vazamentos dessas negociações, e de obter reparação civil por danos já ocorridos, decorrentes de vazamentos pretéritos de tais tratativas (Financial Times Ltd and Others v. The United Kingdom, $\S 71$ )..$^{90}$

No decisum em liça, o Tribunal Europeu dos Direitos Humanos condicionou a quebra do sigilo da(s) fonte(s) jornalística(s) voltada à prevenção do vazamento de informações confidenciais e sensíveis (a) à ausência de meios alternativos, razoáveis e menos intrusivos de se alcançar tal fito e $(b)$ à existência de risco de vazamento cuja gravidade seja suficiente para justificar tal medida e, por outro lado, consubstancie risco definido (Financial Times Ltd and Others v. The United Kingdom, § 69). ${ }^{91}$

Conforme resplandecido alhures, a Grande Câmara do Tribunal Europeu dos Direitos Humanos, em Sanoma Uitgevers B.V. v. The Netherlands $\S \S 90$ a $93,{ }^{92}$ no âmbito do critério da prescrição por lei, rutilou a exigibilidade de que órgão externo às partes (independente) exerça o controle, como instância revisora, da juridicidade da ordem de quebra do sigilo jornalístico, o que implica realizar tal exame firme, inclusive, no critério da necessidade, ao assim proceder:

(a) Efetuar a prévia verificação — antes do fornecimento à autoridade (que o solicitou) do material fruto da quebra do sigilo da(s) fonte(s) jornalística(s) — da predominância, no caso concreto, do interesse público específico da persecução penal atinente à circunstância in concreto sobre o interesse público geral da preservação da inviolabilidade do sigilo jornalístico.

90 Ibidem, loc. cit.

91 Menciona-se, nesse sentido, este trecho do $§ 69$ do aresto da Quarta Seção do TEDH relativo a Financial Times Ltd and Others v. The United Kingdom: "69. ... Moreover, the aim of preventing further leaks will only justify an order for disclosure of a source in exceptional circumstances where no reasonable and less invasive alternative means of averting the risk posed are available and where the risk threatened is sufficiently serious and defined to render such an order necessary within the meaning of Article $10 \S 2$...” Cf. ibidem, loc. cit., grifo nosso.

92 Conselho Da Europa. European Court of Human Rights (Grand Chamber). Sanoma Uitgevers B.V.v. The Netherlands (Application n. 38224/03). Strasbourg, 14 September 2010. Disponível em: http: / /www.echr.coe.int/ECHR. Acesso em: 6 jan. 2011. 
(b) E promover a prevenção do acesso desnecessário a informações capazes de revelar a identidade da fonte. De acordo com essa linha de raciocínio, cabe ao órgão revisor o múnus de cogitar, inclusive, a possibilidade de determinar seja adotada medida igualmente adequada ao fim colimado, porém menos ofensiva à salvaguarda do sigilo jornalístico, ou, ainda, de anular in totum a ordem de quebra do sigilo jornalístico, caso se revele totalmente despicienda. Trata-se de profilaxia indispensável, mesmo que no conteúdo do material cujo sigilo é objeto do pedido de quebra judicial não haja explícita menção a quem atua, no contexto fático em liça, como fonte jornalística. ${ }^{93}$

\section{CORReiÇÃo PARCIAL NO. 2008.72.00.005353-8/SC $\left(7^{\mathrm{a}}\right.$ TURMA DO TRF $\left./ 4^{\mathrm{a}}\right)$}

Em complemento ao eixo temático do presente trabalho, ${ }^{94}$ centrado na jurisprudência remansosa do Tribunal Europeu dos Direitos Humanos acerca da quebra do sigilo das fontes jornalísticas, recorda-se, na seara do Direito brasileiro, o correlato precedente da Correição Parcial $n^{o}$ 2008.72.00.005353-8/SC (Relator, Desembargador Federal Néfi Cordeiro), julgada em 3 de novembro de 2009, em que a Sétima Turma do Tribunal Regional Federal da Quarta Região, em votação unânime,

93 Ibidem, loc. cit.

94 Relativamente à questão da quebra do sigilo jornalístico, outros aportes pretorianos (precedentes estadunidenses, canadenses, brasileiros e argentinos), que também refogem do objeto deste paper (já que voltado este à análise da jurisprudência do Tribunal Europeu dos Direitos Humanos), são estudados no seguinte trabalho doutrinário (do mesmo autor do presente artigo jurídico): Frota, Hidemberg Alves da. Os limites ao sigilo das fontes jornalísticas. ADV Advocacia Dinâmica: informativo semanal, Rio de Janeiro, v. 25, no. 45, pp. 900-897 (paginação decrescente), 13 nov. 2005; Revista Nacional de Direito e Jurisprudência, Ribeirão Preto, v. 6, no. 77, pp. 25-31, mai. 2006; Reflexões sobre quebra judicial do sigilo das fontes jornalísticas, segredo de justiça como limite à liberdade de informação jornalística e divulgação pela mídia do conteúdo de interceptações telefônicas. Revista Magister de Direito Penal e Processual Penal, Porto Alegre, v. 2, no. 9, pp. 22-35, dez. 2005-jan. 2006; A quebra do sigilo das fontes jornalísticas pelo Poder Judiciário. Atuação: Revista Jurídica do Ministério Público Catarinense, Florianópolis, v. 4, no. 8, pp. 137-148, jan.-abr. 2006; Juris Plenum, Caxias do Sul, v. 1, no. 99, mar. 2008. 2 CD-ROM. (Parte integrante da Revista Jurídica Juris Plenum.) 
filiou-se ao pensamento segundo o qual o resguardo do sigilo da fonte deve preponderar, em benefício da liberdade de informação, sobre a promoção de provas direcionadas à persecução penal. Frisou-se a impossibilidade jurídica de se impor a outrem a prática do tipo penal de violação de sigilo profissional (insculpido no art. 154 do Código Penal): ${ }^{95}$

Penal. Processo penal. Correição parcial. Jornalista. Direito ao segreDO DA FONTE.

1. A constitucional preservação do sigilo da fonte não merece exclusão pelo interesse estatal de promover provas para a persecução criminal, prevalecendo na ponderação de valores a liberdade de informação, enquanto pilar do regime democrático de direito.

2. Descabido seria, aliás, obrigar alguém a praticar conduta inclusiva típica - quebra do sigilo profissional - para viabilizar a prova de crimes de outros.

3. Correição parcial denegada. ${ }^{96}$ (grifo nosso)

Consoante narra ${ }^{97}$ o relatório do Desembargador Néfi Cordeiro consignado no caderno processual da indicada Correição Parcial $n^{\circ}$ 2008.72.00.005353-8/SC, determinado membro do Ministério Público Federal ${ }^{98}$ solicitara de Juiz Federal Substituto de Vara Criminal da Justiça Federal de Primeiro Grau da Subseção Judiciária de Florianópolis o "afastamento do direito de preservação da fonte jornalística, no

95 Dispõe o art. 154 do Código Penal, ipsissima verba: "Art. 154 - Revelar alguém, sem justa causa, segredo, de que tem ciência em razão de função, ministério, ofício ou profissão, e cuja revelação possa produzir dano a outrem: Pena - detenção, de três meses a um ano, ou multa. Parágrafo único - Somente se procede mediante representação”. C $f$. Brasil. Código Penal. Disponível em: http://www.planalto.gov.br/ccivil/decreto-lei/del2848.htm. Acesso em: 04 fev. 2011.

96 Brasil. Tribunal Regional Federal da Quarta Região (Sétima Turma). Ementa do acórdão em sede da Correição Parcial no. 2008.72.00.005353-8/SC). Relator: Desembargador Federal Néfi Cordeiro. Porto Alegre, 3 de novembro de 2009. Diário Eletrônico, Porto Alegre, 11 nov. 2009. Disponível em: http: / /www.trf4.jus.br. Também disponível em: http: / /www.justicafederal.jus.br. Acesso em: 17 out. 2010.

97 BRASIL. Tribunal Regional Federal da Quarta Região (Sétima Turma). Trecho do relatório em sede da Correição Parcial no. 2008.72.00.005353-8/SC). Relator: Desembargador Federal Néfi Cordeiro. Porto Alegre, 3 de novembro de 2009. Diário Eletrônico, Porto Alegre, 11 nov. 2009. Disponível em: http://www.trf4.jus.br. Acesso em: 17 out. 2010.

$98 \mathrm{O}$ aresto do TRF $/ 4^{\text {a }}$ Região sub examine não declina o nome do(a) Agente Ministerial em questão (que oficiou no primeiro grau). 
intuito de determinar que a testemunha [jornalista] informasse quem lhe forneceu os dados sigilosos" (concernente a "gravações de interceptações telefônicas” ${ }^{100}$ constantes de inquérito policial que se encontrava sob o manto do segredo de justiça).

O pleito ministerial restou indeferido pelo juízo a quo. Irresignado, o(a) Agente Ministerial requereu correição parcial.

Subindo os autos à Justiça Federal de Segundo Grau, a $7^{\text {a }}$ Turma do $\mathrm{TRF} / 4^{\mathrm{a}}$, capitaneada pelo voto condutor do Desembargador Federal Néfi Cordeiro, baseou-se no parecer alinhavado, naquele feito, pela Procuradora Regional da República Solange Mendes de Souza, a qual, ao dissentir do entendimento firmado na instância original pelo membro do Ministério Público Federal atuante como órgão-autor, reputou incabível a pretendida relativização do sigilo da fonte jornalística, tendo em vista não apenas o fundado risco da quebra do sigilo jornalístico afetar a liberdade de informação (na condição de sustentáculo do regime democrático) e sujeitar o jornalista (caso desenovele a identidade da sua fonte) a realizar o tipo penal de violação de sigilo profissional como também a ausência de indícios elementares de que o profissional do Jornalismo investigado tenha concorrido para a quebra do sigilo judicial.

Posto de outro modo, ponderou-se que o jornalista teria obtido sua informação de maneira lícita - a pessoa natural que lhe serviu de fonte é que teria se portado de forma antijurídica, ao fornecer àquele gravações que deveriam estar infensas à divulgação pública, escudadas pelo elmo do segredo judicial.

Ante a expressiva relevância das considerações expendidas, na qualidade de órgão-interveniente (custos legis), pelo Ministério Público Federal, nos autos da Correição Parcial no. 2008.72.00.005353-8/SC, coligese, abaixo, parcela de tal manifestação ministerial, no tocante a estas ponderações (transcrição caudalosa, porém de alta pertinência):

A decisão combatida sustenta que: sendo o sigilo da fonte meio garantidor da própria liberdade de imprensa, a necessidade desse sigilo está sempre presente; violar o sigilo da fonte é crime (artigo 154 do Código Penal); e é possível iden-

99 Ibidem, loc. cit.

100 Ibidem, loc. cit. 
tificar o autor do crime (a fonte do jornalista) de violação do sigilo judicial por outros meios.

O recurso do MPF colaciona excelente argumentação, sustentando a possibilidade da divulgação de interceptações telefônicas ferir a imagem, a intimidade dos envolvidos (premissa posta no relatório recursal); a relatividade do direito ao sigilo da fonte; a ilegitimidade da fonte; a aferição da necessidade de manutenção do sigilo da fonte pelo Poder Judiciário; a desnecessidade da fonte ilegítima para sustentar a notícia no caso concreto; a preponderância do direito à persecução penal de autores de fatos criminosos e do direito à imagem dos investigados sobre o direito do sigilo da fonte; o status jurídico de "testemunha" do jornalista, obrigado a dizer a verdade, porque somente se contra ele pesasse suspeitas de participação criminosa estaria desobrigado a fazer prova contra si mesmo; e a necessidade de afastamento do sigilo da fonte para identificação do autor de um crime.

Os argumentos apoiam-se, em parte, em conceitos indiscutíveis, tais como a proteção legal ao direito à intimidade, a inexistência de direitos constitucionais absolutos (como reiteradamente afirmado pelo Supremo Tribunal Federal), a distinção entre o tratamento legal dado à testemunha e ao investigado.

Todavia, vejo razões que sustentam o indeferimento do pedido ministerial, na linha da decisão judicial recorrida, ainda que não me filie integralmente aos seus fundamentos. De fato, penso que não importa se subsiste ou não o argumento da decisão judicial acerca da possibilidade de identificação por meio de outras diligências daquele que "vazou" as informações do processo para o jornalista - que é o autor do crime em investigação no inquérito encartado aqui - porque a conclusão de indeferimento do pedido ministerial está ancorado em fundamentos maiores, revelados já no enquadramento que o juízo deu à questão:

"Busca o Ministério Público Federal, em petição de fls. 81/92, decisão que afaste, de forma expressa, o direito do jornalista, responsável por divulgação do conteúdo de escutas telefônicas colhidas no curso de inquérito policial onde houve decretação de sigilo judicial, de manter sua fonte em sigilo.

É fato que a matéria aqui tratada reveste-se de caráter bastante tormentoso, gerando discussões frequentes acerca do tema. A recente decisão do STF, afastando integralmente aplicação da chamada lei de imprensa, trouxe à tona, novamente, maciça exposição de posicionamentos diversos acerca dos limites à liberdade de informação e garantias dadas aos jornalistas no que diz respeito à proteção de suas fontes. 
A Constituição Federal de 1988 é expressa ao manifestar-se acerca do tema, elevando ao patamar de garantia constitucional o acesso livre às informações e o resguardo ao sigilo de fonte. Diz o art. $5^{\circ}, \mathrm{XIV}$, da CF/88:

XN - é assegurado a todos o acesso à informação e resguardado o sigilo da fonte, quando necessário ao exercício profissional.

A preocupação constitucional de manifestamente expressar tais garantias encontra fundamento exatamente no fato de que elas formam, em conjunto com demais garantias também constitucionalmente previstas, o arcabouço legal que sustenta o próprio Estado Democrático de Direito.

A importância de tal tema é tamanha que a lei de imprensa, hoje afastada do mundo jurídico, defendida por muitos como de caráter absolutista por ter sido introduzida no ordenamento legal brasileiro durante período de exceção, também previa em seu texto a proteção às fontes jornalísticas.

Diante de tais observações, qualquer análise a ser feita acerca do tema deve o ser de forma extremamente cuidadosa e atenta".

À essa linha de entendimento, acrescento que, antes de tudo, é preciso perceber a extensão do conceito de sigilo da fonte. O sigilo da fonte e a liberdade de crítica substanciam o próprio direito à liberdade de imprensa. Por sua vez, a liberdade de imprensa é um dos pilares da Democracia. Nestas considerações é que encontramos a ordem de grandeza desse direito e a partir desse ponto é que poderão ser feitas as ponderações de valores em caso de conflitos de direitos.

Assim a questão da relatividade do direito ao segredo de fonte, conferido pela própria redação constitucional, permite o resguardo do sigilo da fonte quando necessário ao exercício profissional, deve ser examinada tendo em mente as premissas anteriormente mencionadas.

Não se pode negar a prioridade do sigilo da fonte, como meio de garantir o exercício profissional, que é a outra face do direito à informação, pilar da democracia. No caso concreto, a decisão não afirmou que estava diante de um direito absoluto, mas ponderou, refletiu sobre o conflito de valores postos.

$O$ direito ao sigilo da fonte cederia diante de várias hipóteses. Obviamente, o direito repugna que o acesso às informações tenha sido obtido por meio criminoso pelo jornalista. Aí a vinculação do jornalista ao fato é direta, seja por autoria ou participação criminosa, na forma do artigo 29 do Código Penal e a disciplina legal a que submete é diversa. Mas na investigação em exame não há qualquer referência a indício 
ou mesmo suspeita de envolvimento do jornalista. Aqui outra pessoa (a fonte do jornalista) cometeu o ilícito de repassar informações cobertas por sigilo.

Na linha do que se expõe, fica revelada a insubsistência de outros argumentos do recurso, tal como a assertiva de que "apenas a licitude de acesso santifica a informação de modo a fazer da fonte um objeto sagrado" (fl. 108). Ocorre que foi justamente o que ocorreu - o jornalista obteve a informação de forma lícita. A ilicitude ocorrida é anterior e independente.

Outra argumentação que não resiste à análise é a que traz à baila interpretação ao artigo 154 do Código Penal, pertinente à violação de sigilo profissional, pois a lição diz exatamente o contrário do que pretende ver o recurso: se o jornalista desproteger sua fonte estará cometendo crime de violação de sigilo profissional. Neste sentido a decisão que restou assim ementada:

Constitucional e penal. Recurso de habeas Corpus. Crime de CAlunia. Lei no. 5.250/69. ARTigos 20 E 23, iII. Delito NÃo CARACTERIZAdo. MATÉRIA JORNALÍSTICA VEICULADA COM O OBJETIVO DE INFORMAR FATOS DE INTERES-

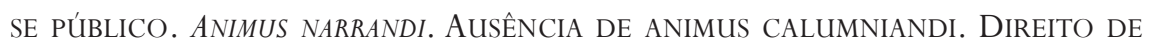
INFORMAR E À INFORMAÇÃO. SIGILO DA FONTE. DirEITO-DEVER DO JORNALISTA. CONFIRMAdA A SENTENÇA QUE TRANCOU INQUÉRITO POLICIAL... 4- A Constituição Federal assegura o direito à informação e resguarda o sigilo da fonte ao jornalista, quando no exercício de sua atividade profissional. 5- O sigilo da fonte é um direito-dever do jornalista. Sua inobservância importa em violação do sigilo profissional e, de consequência, na prática do crime previsto no artigo 154 do CP. 6- Configura manifesto constrangimento ilegal o ato de autoridade que determina o indiciamento de jornalista em inquérito policial caso não quebre o sigilo de suas fontes de informação jornalística. 7- No caso, a atipicidade da conduta do paciente é induvidosa. Incensurável a sentença recorrida. 8- Recurso de habeas corpus improvido. (RHC 199961810022020 Relator(a) JUIZ ARICE AMARAL Sigla do órgão TRF3 Órgão julgador SEGUNDA TURMA Fonte DJU DATA:22/ 03/2000 Decisão A Segunda Turma, por unanimidade, negou provimento à remessa oficial.)

Reconheço que a situação fática traz um paradoxo: ao deixar prevalecer o sigilo da fonte, protege-se também aquele que praticou a conduta criminosa que foi justamente adquirir a informação repassada ao jornalista. Mas de forma alguma pode-se obrigar alguém a praticar outra conduta criminosa - a da quebra do sigilo profissional - para viabilizar a persecução penal de outra e, ainda menos, pode-se por em risco a 
liberdade de informação, enquanto pilar do regime democrático, invocando a ponderação de valores $^{101}$ (grifo nosso).

\section{CONCLUSÃO}

1. Da leitura do art. 10-1 da Convenção Europeia dos Direitos Humanos, percebe-se que a liberdade de expressão, tal como insculpida na $\mathrm{CEDH}$, abarca tanto a liberdade de opinião quanto a liberdade de informação, o que explica a razão da jurisprudência consolidada do Tribunal Europeu dos Direitos Humanos ter avistado em tal artigo a proteção à liberdade de imprensa, uma vez que a liberdade de imprensa abrange seja a liberdade de opinião jornalística, seja a liberdade informação jornalística propriamente dita.

2. No referido dispositivo da Convenção, o Tribunal Europeu dos Direitos Humanos divisou o respaldo normativo para a proteção das fontes jornalísticas, vislumbrada pelo TEDH como condição sine qua non para a liberdade de imprensa: na óptica da Corte de Estrasburgo, sem essa salvaguarda, as fontes podem ser obstadas de assistir a imprensa em informar à coletividade acerca de matérias de interesse público, o que prejudicaria a função fiscalizadora dos meios de comunicação social e a capacidade destes de proporcionarem ao corpo social informações precisas e confiáveis.

3. Em virtude da relevância que possui a proteção das fontes jornalísticas para a liberdade de imprensa em uma sociedade democrática e do potencial efeito inibitório que uma ordem de quebra de sigilo jornalístico teria sobre o exercício dessa liberdade, a jurisprudência remansosa do TEDH (Grande Câmara, Goodwin v. the United Kingdom, § 39; Terceira Seção, Voskuil v. The Netherlands, § 65, e Sanoma Uitgevers B.V.v. The Netherlands § 54, d; Quarta Seção, Roemen and Schmit v. Luxembourg, §

101 Brasil. Ministério Público Federal (Procuradoria Regional da República da Quarta Região). Trechos do parecer ministerial em sede da Correição Parcial no. 2008.72.00.0053538/SC). Parecerista: Procuradora Regional da República Solange Mendes de Souza. Apud Brasil. Tribunal Regional Federal da Quarta Região (Sétima Turma). Trecho do relatório em sede da Correição Parcial no. 2008.72.00.005353-8/SC). Relator: Desembargador Federal Néfi Cordeiro. Porto Alegre, 3 de novembro de 2009. Diário Eletrônico, Porto Alegre, 11 nov. 2009. Disponível em: http://www.trf4.jus.br. Acesso em: 17 out. 2010. Disponível em: http://www.trf4.jus.br. Acesso em: 17 out. 2010. 
46, e Financial Times Ltd and Others v. The United Kingdom, § 59; Primeira Seção, Nordisk Film \& TV A/S v. Denmark) tem considerado incompatíveis com o direito à liberdade de expressão previsto no art. 10 da CEDH as determinações estatais de quebra de sigilo jornalístico, salvo se justificáveis diante de uma preponderante exigência do interesse público, harmônica com as balizas do art. 10-2 da Convenção.

4. A fim de verificar se, no caso concreto, a relativização da garantia do sigilo jornalístico poderia se apoiar nas hipóteses excepcionais delineadas pelo indicado art. 10-2 da CEDH, a Grande Câmara do Tribunal Europeu dos Direitos Humanos, em Goodwin v. the United Kingdom ( $\S \S$ 28 a 46), indagou se a interferência estatal, de acordo com o contexto in concreto, (1) foi prescrita por lei (prescribed by law; prévues par la loi), isto é, se estava prevista no correspondente Direito interno (se possuía respaldo na ordem jurídica do respectivo Estado contratante), (2) visou à finalidade legítima (legitimate aim; but légitime) e (3) era necessária em uma sociedade democrática (necessary in a democratic society; nécessaire dans une société démocratique), ou seja, se correspondia a uma premente necessidade social. Essa formulação tridimensional do princípio da proporcionalidade no tocante ao exame de alegação de quebra de sigilo da(s) fonte(s) jornalística(s) restou observada, na Corte de Estrasburgo, pela Primeira Seção (Nordisk Film \&TV A/S v. Denmark), Segunda Seção (Ernst et Autres c. Belgique, $\S \S 96$ a 105; Tillack c. Belgique, $\S \S 58$ a 68) e Quarta Seção (Roemen and Schmit v. Luxembourg, $\S \S 47$ a 60; Financial Times Ltd and Others v. The United Kingdom, $\S \S 56$ a 73).

5. Já a Terceira Seção do TEDH, em Voskuil v. The Netherlands (§§ 49 a 74), assim como em Sanoma Uitgevers B.V.v. The Netherlands ( $\S 49$ a 63), antes de se debruçar sobre os 3 (três) indicados critérios de aferição, adotou, como primeira baliza, o questionamento quanto à presença de interferência em direito encastoado no art. 10 da CEDH. Afirmado em outros termos, a Terceira Seção da Corte de Estrasburgo, em tais precedentes, averiguou se a atuação do Poder Público, à luz da circunstância concreta analisada, (1) configurou interferência em direito assegurado pelo art. 10 da CEDH, bem assim se a interferência, uma vez comprovada, (2) foi prescrita por lei, (3) voltou-se à finalidade legítima e se mostrou (4) necessária em uma sociedade democrática. 
6. Ao examinar se uma interveniência estatal na garantia do sigilo jornalístico resta prescrita por lei, o Tribunal Europeu dos Direitos $\mathrm{Hu}$ manos perquire se houve a chancela do Direito Legislado (Grande Câmara, Goodwin v. the United Kingdom, § 29; Primeira Seção, Nordisk Film \& TV A / S v. Denmark; Segunda Seção, Tillack c. Belgique, $\S \S 32$ e 58; Terceira Seção, Sanoma Uitgevers B.V.v.The Netherlands, § 51, e Voskuil v. The Netherlands, § 50; Quarta Seção, Roemen and Schmit v. Luxembourg, § 49, e Financial Times Ltd and Others v. The United Kingdom, § 57), encontrando tal respaldo, por vezes, na legislação processual penal apontada pelo Estado contratante demandado (Segunda Seção, Tillack c. Belgique, §§ 32 e 58; Terceira Seção, Sanoma Uitgevers B.V. v. The Netherlands, § 51, e Voskuil v. The Netherlands, § 50; Quarta Seção, Roemen and Schmit v. Luxembourg, § 49).

7. Em Financial Times Ltd and Others v. The United Kingdom (§ 57), a Quarta Seção do Tribunal Europeu dos Direitos Humanos considerou, além da previsão em ato legislativo, o supedâneo haurido da jurisprudência consolidada no respectivo Direito interno, a exemplo de como procedera a Grande Câmara da Corte de Estrasburgo em Goodwin v. the United Kingdom (§ 33).

8. Naquela oportunidade, a Grande Câmara ponderou a relevância de que conceitos legais que confiram certa margem discricionária à interferência do Poder Público no exercício de determinado direito recebam construções judiciais que tenham o condão de tornar mais claro ao destinatário da lei em que consistiria o tipo ilícito delineado pelo legislador (Goodwin v. the United Kingdom, § 33).

9. É que não bastaria insculpir em lei formal o tipo do ilícito: seria necessário que o destinatário da norma pudesse, antes de cogitar a prática da conduta prevista no tipo, ter condições razoáveis de compreender, mediante a leitura do dispositivo legal e, se necessário, eventual assessoramento jurídico, o caráter ilícito da conduta proscrita, de modo que a redação do texto legal propiciasse um grau de precisão que tornasse possível ao destinatário da norma antever os possíveis desdobramentos jurídicos da conduta cogitada (Goodwin v. the United Kingdom, § 31).

10. Ao apreciar recurso contrário ao acórdão da Terceira Seção do TEDH em Sanoma Uitgevers B.V.v. The Netherlands, a Grande Câmara da Corte de Estrasburgo, em 14 de setembro de 2010, reiterou tal pon- 
deração ( $§ 81)$ em termos mais sucintos, ao ressaltar que a lei deve ser adequadamente acessível (à compreensão do destinatário da norma) e previsível (em seus efeitos), para que, assim, o indivíduo possa se pautar pelas balizas extraídas de tal preceito.

11. Acrescentou, baseada na jurisprudência remansosa do TEDH e em repulsa a normas que proporcionem poderes incondicionados aos agentes públicos, que a lei deve indicar, com clareza suficiente, o escopo da discricionariedade cometida à autoridade estatal competente para interferir na esfera jurídica alheia e os meios de exercício dos correspondentes poderes (Grande Câmara, Sanoma Uitgevers B.V.v. The Netherlands, $\S 82)$.

12. Esplendeu a exigibilidade, principalmente em casos de tutelas de urgência (em que a autoridade a pleitear o descerramento do sigilo jornalístico, premida pelo tempo, não tem, por vezes, a oportunidade de alinhavar uma motivação mais minuciosa), de que órgão externo ao Poder Executivo e às demais partes, na qualidade de instância revisora (órgão de âmbito judicial ou extrajudicial), faça, de maneira objetiva e imparcial, o controle do ato estatal de quebra do sigilo jornalístico.

13. A Grande Câmara, ainda em Sanoma Uitgevers B.V. v. The Netherlands ( $\S 94,100$ e 101), ao se reportar ao critério da prescrição por lei, referiu-se também à qualidade da lei: embora a quebra do sigilo da(s) fonte(s) jornalística(s) contasse, in casu, com previsão em lei formal (Código de Processo Penal), a qualidade da lei se revelara deficiente ou insuficiente aos olhos do órgão maior do TEDH, porque, no âmbito do Estado contratante demandado (o Reino dos Países Baixos), a função de órgão revisor da ordem de quebra do sigilo jornalístico, depois da entrada em vigência do art. 96a do Estatuto Processual Penal neerlandês, passou a ser incumbência de membro do Ministério Público, o qual, como parte interessada na persecução penal e por não constituir órgão do Poder Judiciário, não poderia assegurar a necessária independência no controle, como instância revisora, da referida ordem.

14. Ainda em relação a Sanoma Uitgevers B.V.v.The Netherlands, a Grande Câmara do Tribunal Europeu dos Direitos Humanos frisou que aferir se uma interferência estatal no exercício de direito fundamental está de acordo com a lei ou prescrita por lei significa ter presente não apenas o Direito Legislado como também atos administrativos com conteúdo 
de lei, inclusive atos normativos emanados de órgãos de fiscalização profissional, bem assim a jurisprudência consolidada (Grande Câmara, Sanoma Uitgevers B.V.v. The Netherlands, § 83). Preconizou, em suma, o acolhimento da acepção de lei em sentido material ou substantivo, em detrimento da adoção da acepção de lei stricto sensu ou em sentido meramente formal (mesmo parágrafo).

15. Em mesma direção se situou a Segunda Seção do TEDH em Ernst et Autres c. Belgique, de 15 de julho de 2003, ao lembrar que a jurisprudência iterativa da Corte de Estrasburgo enxerga a lei em sentido material e não formal (§ 96), a abarcar, no campo de incidência da acepção de lei, o Direito construído com base na interpretação legal feita pelos órgãos judiciários competentes ( 996$)$.

16. Para fins de quebra do sigilo da(s) fonte(s) jornalística(s), finalidade(s) legítima(s) pode(m) dizer respeito (a) ao propósito de coibir a divulgação midiática de informações confidenciais de uma sociedade empresária (Grande Câmara, Goodwin v. the United Kingdom, §§ 11 e 35), (b) ao intento de prevenir a desordem e/ou crime (Quarta Seção, Roemen and Schmit v. Luxembourg, § 50; Terceira Seção, Sanoma Uitgevers B. V. v. The Netherlands, §53, e Voskuil v. The Netherlands, §§54 e 56), (c) ao duplo desiderato de proteger direitos alheios e evitar o vazamento de informações fornecidas em caráter confidencial (Quarta Seção, Financial Times Ltd and Others v. The United Kingdom, § 58), (d) de prevenir desordem ou crime e salvaguardar direitos alheios (Primeira Seção, Nordisk Film \& $T V A / S$ v. Denmark), (e) ao triplo fim de impedir a divulgação de informações confidenciais, proteger a reputação alheia e assegurar a autoridade e a imparcialidade do Poder Judiciário (Segunda Seção, Ernst et Autres c. Belgique, § 98), e (f) de visar à defesa da ordem pública, à prevenção de infrações penais e da divulgação de informações confidenciais e à proteção da reputação alheia (Segunda Seção, Tillack c. Belgique, § 59).

17. Ao examinar as alegações do respectivo Estado contratante de que houve finalidade(s) legítima(s) a nortear(em) determinado procedimento estatal de quebra de sigilo jornalístico, o Tribunal Europeu dos Direitos Humanos, por vezes, não perscruta a presença de todas as finalidades invocadas pelo polo passivo, bastando-lhe, para reputar contemplada tal exigência, concluir que se encontra comprovada nos autos parcela das finalidades aludidas pelo Estado requerido: 
17.1. Em Goodwin v. the United Kingdom, o Estado contratante arguiu os propósitos de proteger o sigilo empresarial e de promover a prevenção criminal (§ 35). A Grande Câmara da Corte de Estrasburgo, ao acolher o primeiro argumento, dispensou a si mesma de proceder à análise do segundo argumento $(\S 36)$.

17.2. E, em Voskuil v. The Netherlands, o Estado contratante mencionou os fins de proteger a reputação ou os direitos alheios (notadamente, a integridade moral do Poder Judiciário dos Países Baixos e da Polícia de Amsterdã), de resguardar a segurança pública e de efetuar a prevenção de crime ou de desordem (§ 54). A Terceira Seção do TEDH se ateve a aceitar o argumento da prevenção criminal, sem se posicionar, portanto, acerca das demais finalidades invocadas pelo polo passivo ( $\$ 56$ ).

18. Já em Financial Times Ltd and Others v. The United Kingdom (§ 58), no qual o Estado contratante, em sua peça de defesa, indicou os fitos de (1) resguardar os direitos alheios, de (2) se acautelar contra o vazamento de informações repassadas de forma confidencial e (3) de prevenir a prática delituosa, a Quarta Seção da referida Corte Europeia, além de abraçar os dois primeiros argumentos, analisou a terceira justificativa, rejeitando-a, porque a prevenção criminal, atribuição típica do Poder Público, não se aplicava ao caso vertente, porquanto, in casu, a quebra do sigilo jornalístico tinha sido requerida, não por órgão público, mas por entidade privada não estatal (sociedade empresária belga), que anelara, ao solicitar tal provimento estatal, identificar as pessoas que forneceram a órgãos de comunicação social informações sigilosas cuja divulgação midiática havia lhe ocasionado consideráveis prejuízos financeiros ( $\$ 58$ e 16).

19. Ao avaliar se dada flexibilização no resguardo do sigilo jornalístico afrontou o art. 10 da CEDH, a Corte de Estrasburgo tende a ser mais rigorosa ao final do julgamento do mérito, quando da análise estribada justamente no último critério, por meio do qual esquadrinha se uma interferência estatal se demonstra necessária em uma sociedade democrática.

20. Em Goodwin v. the United Kingdom, de 27 de março de 1996, a Grande Câmara do Tribunal Europeu dos Direitos Humanos, ao fundear os alicerces da visão do TEDH sobre o descobrimento do manto do sigilo da(s) fonte(s) jornalística(s), postulou estas balizas: 
20.1. Restringe-se às circunstâncias excepcionais, isto é, adstringe-se às situações em que estão em jogo interesses públicos ou privados de cunho vital (§37).

20.2. A margem discricionária para a autoridade nacional aferir se existe, na circunstância com a qual se depara, uma necessidade social premente de se relativizar o sigilo jornalístico encontra-se circunscrita pelo interesse da sociedade democrática de assegurar e manter a liberdade de imprensa, aspiração coletiva que se reveste de peso considerável, ao se sopesar se, em dado contexto concreto, a restrição ao caráter inviolável do sigilo da(s) fonte(s) jornalística(s) foi proporcional à finalidade legítima perseguida pelo Estado que assim procedeu (\$ 40).

20.3. Incumbe à Corte de Estrasburgo o múnus de verificar se o Estado contratante impôs, de fato, temperamentos à inviolabilidade do sigilo jornalístico, e, em caso afirmativo, se, ao fazê-lo, estribou-se em motivos relevantes e suficientes ( $\$ 40)$, de tal sorte que tenha existido um razoável nexo de proporcionalidade entre, de um lado, a finalidade legítima que impeliu o Estado demandado a emitir ordem de quebra de sigilo da(s) fonte(s) jornalística(s) e, de outra banda, os meios adotados pelo aparelho estatal a fim de alcançar esse desiderato.

21. Ao esposar síntese da construção pretoriana acerca do sigilo jornalístico inaugurada em Goodwin v. the United Kingdom, a Quarta Seção do Tribunal Europeu dos Direitos Humanos, em Roemen and Schmit v. Luxembourg, de 25 de fevereiro de 2003, consignou 3 (três) requisitos (§ 51) para se esclarecer se a flexibilização do sigilo da(s) fonte(s) jornalística(s) foi necessária em uma sociedade democrática: (1) se a interferência contemplou necessidade social premente, (2) se foi proporcional à finalidade legítima perseguida e (3) se as razões declinadas pelas autoridades nacionais, ao justificarem as medidas restritivas, foram relevantes e suficientes.

22. Articulando com mais minudência tais balizas, a Terceira Seção da Corte de Estrasburgo, em Sanoma Uitgevers B.V.v. The Netherlands, de 31 de março de 2009, reconheceu a margem discricionária para os Estados signatários da Convenção Europeia dos Direitos Humanos analisarem se, em determinada circunstância, faz-se presente uma necessidade social premente que torne, com o perdão da redundância, necessária em uma sociedade democrática, a quebra do sigilo da(s) fonte(s) jornalística(s), ao 
mesmo tempo que salientou a competência do Tribunal Europeu de Direitos Humanos, como reflexo da supervisão europeia sobre a atuação dos Estados contratantes, de proferir a decisão final nos casos levados à sua apreciação (inclusive na qualidade de instância revisora de atos decisórios proferidos pelo respectivo Poder Judiciário nacional), relativamente à controvérsia acerca da congruência de tal medida estatal com a proteção à liberdade de expressão de que cuida o art. 10 da indicada Convenção ( $\$ 54$, alínea $a$ ), tendo em perspectiva não apenas verificar se a atuação discricionária do Estado demandado foi razoável, cuidadosa e de boa-fé como também julgar o meritum causae com esteio em uma visão ampla do caso concreto analisado, ou seja, efetuar o exame da interveniência estatal "à luz do caso como um todo" (Sanoma Uitgevers B.V. v. The Netherlands, $\S 54$, alínea $b$ ).

23. Enfatizou que, amparado nas informações prestadas pelo Estado contratante, cabe ao Tribunal Europeu dos Direitos Humanos averiguar se as autoridades nacionais avaliaram de forma adequada os fatos relevantes e se procederam em harmonia com o plexo normativo do art. 10 da $\mathrm{CEDH}$, o que significa aferir se houve motivos suficientes e relevantes $\mathrm{e}$ se a medida adotada foi proporcional à finalidade legítima em mira (Sanoma Uitgevers B.V.v. The Netherlands, § 54, alínea c).

24. Recordou que os temperamentos à inviolabilidade do sigilo da(s) fonte(s) jornalística(s) somente se justificam quando existe um interesse público cuja densidade, na situação in concreto, sobreponha-se à importância do sigilo jornalístico em uma sociedade democrática e ao potencial efeito inibitório (chilling effect ou effet inhibant) da quebra do sigilo sobre o exercício da liberdade de imprensa (Sanoma Uitgevers B.V. v. The Netherlands, $\S 54$, alínea d).

25. Percebe-se, assim, a preferência do Tribunal Europeu dos Direitos Humanos por intervenções estatais tópicas e sua oposição a medidas instrutórias que não se revelem indispensáveis ou que se denotem exorbitantes, a exemplo de devassas (materializadas, por vezes, por intermédio de buscas e apreensões indiscriminadas). Ilustrativos, nesse aspecto, precedentes da Quarta Seção (Roemen and Schmit v. Luxembourg, $\S \S 8^{\circ}$ a $13,15,17,52,57$ e 58, e Financial Times Ltd and Others v. The United Kingdom, § 71), da Primeira Seção (Nordisk Film \&TV A/S v. Denmark), da Segunda Seção (Ernst et Autres c. Belgique, §§ 101 a 105, e Tillack c. Bel- 
gique, $\S \S 6^{\circ}$ a $9^{\circ}$ e 66 a 68) e da Terceira Seção (Voskuil v. The Netherlands, $\S 70)$ do TEDH.

26. Medidas instrutórias indiscriminadas, além de consistirem em intervenções desnecessárias na esfera jurídica dos jornalistas e de terceiros que com estes colaboram sob a condição de anonimato ou de sigilo, acarretam efeito inibitório excessivo sobre jornalistas, órgãos de comunicação social e eventuais fontes jornalísticas.

27. Com efeito, a Terceira Seção da Corte de Estrasburgo, em Voskuil v. The Netherlands ( $\$ 70$ ), de 22 de novembro de 2007, pontificou que medidas de quebra de sigilo jornalístico de longo alcance têm o condão de desencorajar pessoas que possuem informações verdadeiras e precisas de informarem aos meios de comunicação social a prática de ilícitos graves, como os que concerniam àqueles autos (tráfico de armas em Amsterdã).

28. Em outras palavras, na circunstância acima, a Terceira Seção do Tribunal Europeu dos Direitos Humanos enxergou a intervenção estatal como prescrita por lei (encastoada no art. 294 do Estatuto Processual Penal dos Países Baixos) e direcionada à finalidade legítima (prevenção criminal), porém não a reputou necessária em uma sociedade democrática, ao divisar a prisão provisória de jornalista, durante 17 (dezessete) dias, medida judicial de longo alcance a inibir fontes jornalísticas de fornecerem à imprensa informações precisas e verdadeiras sobre ilícitos da espécie de que cuidavam aqueles autos — tráfico de armas (Voskuil v. The Netherlands, $\S \S 50$ a 56, 60, 71 e 72).

29. Com razão, a Quarta Seção do TEDH, em Financial Times Ltd and Others v. The United Kingdom ( $\$ 63$ ), de 15 de dezembro de 2009, observa que o efeito inibitório decorrente da quebra do sigilo bancário não incide somente sobre a pessoa que é, naquele caso concreto, a fonte do jornalista (efeito dissuasório, ante o risco e o temor de que sua identidade seja revelada) mas também sobre a reputação do respectivo órgão de comunicação social (o fato de ser o órgão em relação ao qual foi exigida a identificação de determinada fonte teria efeito dissuasório sobre outras pessoas —inclusive do público — que, por ventura, tivessem a eventual predisposição ou o potencial de lhe fornecer, de modo sigiloso, informações de interesse público, e, por receio de terem suas identidades posteriormente descobertas, mudariam de ideia, optando por não sub- 
sidiarem tais informações ao respectivo órgão de comunicação social), além de frustrar a parcela do público que almeja ter acesso a informações de interesse público repassadas por fontes anônimas. Mesma observação registrada em 14 de setembro de 2010, pela Grande Câmara da Corte de Estrasburgo (Sanoma Uitgevers B.V.v. The Netherlands, § 89).

30. Assinalou a Quarta Seção do TEDH, no acórdão acima citado (Financial Times Ltd and Others v. The United Kingdom, § 63, in fine), que a conduta da fonte (a licitude ou ilicitude com que se houve uma pessoa, ao divulgar informações à imprensa) nunca deve ser o fator decisivo para se determinar a necessidade de uma ordem de quebra de sigilo jornalístico: ainda que relevante, convém que figure como mais um fator, dentre outros, a ser considerado, ao se avaliar o coeficiente de proporcionalidade da medida estatal impugnada.

31. No precedente em testilha, ressaltou-se a presença de efeito inibitório quando o jornalista é compelido a colaborar com a identificação de fontes anônimas, independente dos documentos requisitados pela autoridade judiciária contemplarem tal finalidade de modo direto ou indireto (Financial Times Ltd and Others v. The United Kingdom, § 70).

32. No decisum em liça, o Tribunal Europeu dos Direitos Humanos condicionou a quebra do sigilo da(s) fonte(s) jornalística(s) voltada à prevenção do vazamento de informações confidenciais e sensíveis (a) à ausência de meios alternativos, razoáveis e menos intrusivos de se alcançar tal fito e (b) à existência de risco de vazamento cuja gravidade seja suficiente para justificar tal medida e, por outro lado, consubstancie risco definido (Financial Times Ltd and Others v. The United Kingdom, § 69).

33. Conforme resplandecido alhures, a Grande Câmara do Tribunal Europeu dos Direitos Humanos, em Sanoma Uitgevers B.V. v. The Netherlands $\S \S 90$ a 93, no âmbito do critério da prescrição por lei, rutilou a exigibilidade de que órgão externo às partes (independente) exerça o controle, como instância revisora, da juridicidade da ordem de quebra do sigilo jornalístico, o que implica realizar tal exame firme, inclusive, no critério da necessidade, ao assim proceder:

33.1. Efetuar a prévia verificação — antes do fornecimento à autoridade (que o solicitou) do material fruto da quebra do sigilo da(s) fonte(s) jornalística(s) — da predominância, no caso concreto, do interesse público específico da persecução penal atinente à circunstância in concreto so- 
bre o interesse público geral da preservação da inviolabilidade do sigilo jornalístico.

33.2. E promover a prevenção do acesso desnecessário a informações capazes de revelar a identidade da fonte. De acordo com essa linha de raciocínio, cabe ao órgão revisor o múnus de cogitar, inclusive, a possibilidade de determinar seja adotada medida igualmente adequada ao fim colimado, porém menos ofensiva à salvaguarda do sigilo jornalístico, ou, ainda, de anular in totum a ordem de quebra do sigilo jornalístico, caso se revele totalmente despicienda. Trata-se de profilaxia indispensável, mesmo que no conteúdo do material cujo sigilo é objeto do pedido de quebra judicial não haja explícita menção a quem atua, no contexto fático em liça, como fonte jornalística.

34.1. Em complemento ao eixo temático do presente trabalho, centrado na jurisprudência remansosa do Tribunal Europeu dos Direitos Humanos acerca da quebra do sigilo das fontes jornalísticas, recorda-se o correlato precedente da Correição Parcial no. 2008.72.00.0053538/SC (Relator, Desembargador Federal Néfi Cordeiro), julgada em 3 de novembro de 2009, em que a Sétima Turma do Tribunal Regional Federal da Quarta Região, em votação unânime, filiou-se ao pensamento segundo o qual o resguardo do sigilo da fonte deve preponderar, em benefício da liberdade de informação, sobre a promoção de provas voltadas à persecução penal. Frisou-se a impossibilidade jurídica de se impor a outrem a prática do tipo penal de violação de sigilo profissional (o art. 154 do Código Penal).

34.2. Em tal julgado, a $7^{\mathrm{a}}$ Turma do $\mathrm{TRF} / 4^{\mathrm{a}}$, capitaneada pelo voto condutor do Desembargador Federal Néfi Cordeiro, baseou-se no parecer alinhavado pela Procuradora Regional da República Solange Mendes de Souza, a qual, ao dissentir do entendimento firmado na instância original pelo membro do Ministério Público Federal atuante como órgãoautor, reputou incabível a pretendida relativização do sigilo da fonte jornalística, tendo em vista não apenas o fundado risco da quebra do sigilo jornalístico afetar a liberdade de informação (na condição de sustentáculo do regime democrático) e sujeitar o jornalista (que desnovela a identidade da sua fonte) a realizar o tipo penal de violação de sigilo profissional como também a ausência de indícios elementares de que o 
profissional do Jornalismo investigado tenha concorrido para a quebra do sigilo judicial.

34.3. Em outros dizeres, ponderou-se que o jornalista teria obtido sua informação de maneira lícita — a pessoa natural que lhe serviu de fonte é que teria se portado de forma antijurídica, ao fornecer àquele gravações que deveriam estar infensas à divulgação pública, escudadas pelo elmo do segredo judicial.

\section{REFERÊNCIAS}

Brasil. Código Penal. Disponível em: http: //www.planalto.gov.br/ccivil/ decreto-lei/de12848.htm. Acesso em: 04 fev. 2011.

, Tribunal Regional Federal da Quarta Região (Sétima Turma). Acórdão em sede da Correição Parcial no. 2008.72.00.005353-8/ SC). Relator: Desembargador Federal Néfi Cordeiro. Porto Alegre, 3 de novembro de 2009. Diário Eletrônico, Porto Alegre, 11 nov. 2009. Disponível em: http: / / www.trf4.jus.br. Também disponível em: http://www.justicafederal.jus.br. Acesso em: 17 out. 2010.

Conselho da Europa, Convenção para a Protecção dos Direitos do Homem e das Liberdades Fundamentais, com as modificações introduzidas pelos Protocolos ns. 11 e 14 .

, Convention for the Protection of Human Rights and Fundamental Freedoms as amended by Protocols N. 11 and N. 14. Disponível em: http: / / conventions.coe.int/treaty/en/Treaties/Html/005.htm. Acesso em: 5 jan. 2011.

, Cour européenne des Droits de l'Homme (deuxième section). Ernst et Autres v. Belgique (Requête n. 33400/96). Strasbourg, 15 juillet 2003. Disponível em: http://www.echr.coe.int/ECHR. Acesso em: 6 jan. 2011.

, Tillack c. Belgique (Requête n. 20477/05). Strasbourg, 15 juillet 2003. Disponível em: http://www.echr.coe.int/ECHR. Acesso em: 6 jan. 2011.

, European Court of Human Rights (First Section). Nordisk Film \&TV A/S v. Denmark (Application n. 40485/02). Strasbourg, 8 De- 
cember 2005. Disponível em: http: //www.echr.coe.int/ECHR. Acesso em: 6 jan. 2011.

, European Court of Human Rights (Fourth Section). Financial Times Ltd and Others v. The United Kingdom (Application n. 821/03). Strasbourg, 15 December 2009. Disponível em: http://www.echr.coe. int/ECHR. Acesso em: 6 jan. 2011.

, Roemen and Schmit v. Luxembourg (Application n. 51772/99). Strasbourg, 25 February 2003. Disponível em: http://www.echr.coe. int/ECHR. Acesso em: 6 jan. 2011.

, European Court of Human Rights (Grand Chamber). Goodwin v. the United Kingdom (Application n. 17488/90). Strasbourg, 27 March 1996. Disponível em: http://www.echr.coe.int/ECHR. Acesso em: 6 jan. 2011.

, Sanoma Uitgevers B. V. v. The Netherlands (Application $\mathrm{n}$. 38224/03). Strasbourg, 14 September 2010. Disponível em: http: / / www.echr.coe.int/ECHR. Acesso em: 6 jan. 2011.

, European Court of Human Rights (Third Section). Voskuil v. The Netherlands (Application n. 64752/01). Strasbourg, 22 November 2007. Disponível em: http: / / www.echr.coe.int/ECHR. Acesso em: 6 jan. 2011.

, Sanoma Uitgevers B. V. v. The Netherlands (Application $\mathrm{n}$. 38224/03). Strasbourg, 31 March 2009. Disponível em: http: / /www. echr.coe.int/ECHR. Acesso em: 6 jan. 2011.

, Protocol N. 11 to the Convention for the Protection of $\mathrm{Hu}-$ man Rights and Fundamental Freedoms, E.T.S. 155, entered into force 1 November 1998. Disponível em: http://www1.umn.edu/humanrts/euro/z30prot11.html. Acesso em: 5 jan. 2011.

, The Court in brief. Disponível em: http://www.echr.coe.int/ NR/rdonlyres / DF074FE4-96C2-4384-BFF6-404AAF5BC585/0 / Brochure_en_bref_EN.pdf. Acesso em: 5 jan. 2011.

Fagundes, Miguel Seabra, O controle dos atos administrativos pelo Poder Judiciário, 7a. ed., Rio de Janeiro, Forense, 2005.

Frota, Hidemberg Alves da, O princípio tridimensional da proporcionalidade no Direito Administrativo: um estudo à luz da Principiologia do Direito Constitucional e Administrativo, bem como da jurisprudência brasileira e estrangeira, Rio de Janeiro, GZ, 2009. 
Gagliano, Pablo Stolze e Pamplona filho, Rodolfo, Novo curso de direito civil: parte geral, 10a. ed., São Paulo, Saraiva, v. 1.

Wikipedia, Anheuser-Busch InBev. Disponível em http://en.wikipedia. org/wiki/Anheuser-Busch_InBev. Acesso em: 26 jan. 2011.

Constitutional Reform Act 2005. Disponível em http:// en.wikipedia.org/wiki/Constitutional_Reform_Act_2005. Acesso em: 26 jan. 2011.

, High Court of Justiciary. Disponível em http: / / en.wikipedia. org/wiki/High_Court_of_Justiciary. Acesso em: 26 jan. 2011.

Lords of Appeal in Ordinary. Disponível em http:// en.wikipedia.org/wiki/Lords_of_Appeal_in_Ordinary. Acesso em: 26 jan. 2011.

Judicial functions of the House of Lords. Disponível em: http: / / en.wikipedia.org/wiki/Judicial_functions_of_the_House_of_ Lords. Acesso em: 26 jan. 2011.

, Supreme Court of the United Kingdom. Disponível em: http://en.wikipedia.org/wiki/Supreme_Court_of_the_United_Kingdom. Acesso em: 26 jan. 2011.

Wikipédia, Holanda (topônimo). Disponível em http://pt.wikipedia. org/wiki/Holanda_(topônimo). Acesso em: 25 dez. 2010. 